\title{
Social wasp species of Mischocyttarus (Phi) related to M. alfkenii (Ducke) and M. paraguayensis Zikán (Hymenoptera, Vespidae, Polistinae)
}

\author{
Orlando Tobias Silveira ${ }^{1}$
}

${ }^{1}$ Coordenação de Zoologia, Museu Paraense Emilio Goeldi-MCT, Campus de Pesquisas, Av. Perimetral 1901, Bairro da Terra Firme, 66077-530 Belém-PA, Brazil. orlando@museu-goeldi.br

\begin{abstract}
Social wasp species of Mischocyttarus (Phi) related to M. alfkenii (Ducke) and M. paraguayensis Zikán (Hymenoptera, Vespidae, Polistinae). A revision of the taxonomic status and an identification key are presented for species of the genus Mischocyttarus related to M. alfkenii (Ducke) and M. paraguayensis Zikán. Seven new species are proposed in the alfkenii and basimacula groups (M. achagua sp. nov.; M. arawak sp. nov.; M. awa sp. nov.; M. embera sp. nov.; M. muisca sp. nov.; M. uniformis sp. nov.; M. waunan sp. nov.), with five new synonymies [M. mamirauae Raw = M. alfkenii (Ducke); . alfkenii excrucians Richards $=M$. flavicornis nigricornis Zikán $=$ M. flavicornis Zikán; . basimacula superpictus Richards $=$ M. basimacula $($ Cameron)]. Specific status is also newly recognized for $M$. trinitatis Richards. Two new species are described in the paraguayensis and bahiae group ( $M$. suzannae sp. nov.; M. tayacaja sp. nov.), while fifteen new synonymies are proposed (M. aracatubaensis Zikán = M. araujoi Zikán $=M$. costalimai Zikán $=M$. gilvus Zikán $=M$. infrastrigatoides Zikán $=M$. infrastrigatus Zikán $=M$. infrastrigatus Zikán $=M$. ornatulus Zikán $=M$. riograndensis Richards $=M$. rivulorum Richards $=M$. schrottkyi Zikán $=M$. scitulus Zikán $=M$. similaris Zikán $=$ M. similatus Zikán = M. paraguayensis Zikán). These numbers change the picture of diversity in these species groups, as partly found in Richards's revision, published in 1978, reflecting higher diversity in northern Andean areas than in the Brazilian Atlantic region.
\end{abstract}

KEYWORDS. Insecta; Neotropical; new species; taxonomy.

Mischocyttarus de Saussure, 1853 is the largest genus of social vespids with more than two-hundred species arranged in eleven subgenera (Silveira 2008). It is essentially a Neotropical taxon, with a few species occurring north of México (Cooper 1996a, 1996b, 1997a, 1997b, 1998a, 1998b; Richards 1941, 1945, 1978; Silveira 2006, 2008; Zikán 1935, 1949). Social organization is relatively simple, with a dominance hierarchy being established among females in a colony by way of physical attacks and oophagy. Nests usually consist of an open comb attached by a peduncle to the substrate (Gadagkar 1991; Jeanne 1980; Richards 1971; Wenzel 1991, 1998).

Ducke (1913) established the present-day concept of the genus by synonymizing to Mischocyttarus the names Monacanthocnemis Ducke and Megacanthopus Ducke, created by him to receive species transferred from Polybia Lepeletier that presented evident morphological differences and simpler social organization (Ducke 1904; 1905a). After the descriptions of $M$. cerberus and $M$. bertonii by Ducke (1918) (his last descriptions of social wasp species, jointly with Polistes flavopictus), only in the 1930s Bequaert and Salt (1931), Bequaert (1933), and especially Zikán (1935) resumed the publication of new species or varieties in Mischocyttarus, providing detailed descriptions in a modern style. However, only Richards (1941) came to elaborate an internal classification founded on subgenera and species groups. This classification was consolidated in a subsequent revision of Mischocyttarus by Richards (1945), but was largely ignored by Zikán (1949) in an equally extensive study of the genus, with descriptions of more than one hundred new species and varieties.

Megacanthopus alfkenii was first proposed by Ducke (1904) with a short description in which morphology and nest architecture were compared with those of a taxonomically distant species, Mischocyttarus surinamensis (de Saussure, 1854). The new species was collected by Ducke in the Brazilian states of Amapá (Mazagão and Oiapoque) and Pará (Óbidos) in the eastern Amazon region. Only in subsequent papers (Ducke 1905a, b) did the author specifically describe characters such as the shape of the antennae of the male and publish photographs of nests (one belonging to the type series from Amapá [Fig. 24b] and the other from the lower Rio Japurá [Fig. 24a]). The distribution limits of the species were therefore extended westward to include locations along the middle Amazonas-Solimões River (Tefé and Japurá). Richards (1978) designated as the lectotype a female from Rio Villanova (Amapá) deposited in the São Paulo Museum (MZSP). The literature also mentions three other female paralectotypes from Amapá: two in the Paris Museum (MNHN; Richards 1978) and a third in the Bern Museum (NHMB; Obrecht \& Huber 1993; see also Carpenter 1999). An additional female with the same data as the lectotype is maintained in the Museu Goeldi (MPEG).

Mischocyttarus paraguayensis was described by Zikán (1935) from females and males from Paraguay. Richards (1945) misused the name while dealing with a different species, which was subsequently described by Zikán (1949) with the name 
M. consimilis. In this latter work, Zikán presented a long redescription of M. paraguayensis, with illustrations and photograph of the nest, and expanded the distribution of the species to include the states of Santa Catarina and Rio Grande do Sul, in Brazil. Richards (1978) designated a male deposited in the São Paulo Museum (MZSP) as lectotype, with paralectotypes in the Zikán Collection in Rio de Janeiro (IOC).

Of the two species considered above, only M. alfkenii was actually examined by Richards (1945), placed by him in the subgenus Kappa, group of M. cubensis (de Saussure, 1854), which could be distinguished from the alternative group of $M$. flavitarsis (de Saussure, 1854) by the shorter $13^{\text {th }}$ antennal article of the male, among other characters. In his last major study of the genus, Richards (1978) created the new subgenus Monocyttarus (= Phi de Saussure) to accommodate the groups of M. flavitarsis and M. cubensis of the 1941 and 1945 papers. However, as presented in 1978, Richards's species groups had already been considerably modified, with M. alfkenii and M. paraguayensis (and many other species described by Zikán in 1935 and 1949) being placed into a large group of " $M$. alfkenii and $M$. consimilis". The course of the extensive changes in the infrageneric classification of Mischocyttarus since 1941was discussed by Silveira (2008) in the first cladistic study of the genus treating all subgenera and species groups. In that work, while limited support was found for monophyly of the subgenus $P h i$, none of the species groups considered in Richards (1978), or any other grouping of species in Phi resulted monophyletic in a consistent way. An exception was a clade formed by part of the species of the group of $M$. flavitarsis. However, based on purely phenetic aspects and as reference for further studies, Silveira (2008) presented a revised and extended version of Richards's arrangement of species groups, with new diagnoses.

In this study, a revision is presented of the taxonomic status of species-level taxa in two of the species groups of Phi, reported by Silveira (2008) as "M. alfkenii and M. basimacula" and " $M$. infrastrigatus and $M$. costalimai" respectively (see below). These two groups comprise a significant portion of the taxonomic diversity of the subgenus in South America, in Andean regions and especially southeastern Brazil from where many species were described by Zikán $(1935,1949)$.

\section{MATERIAL AND METHODS}

Source collections. This study benefited from loans from various institutions (see below and the Acknowledgments section), and especially from visits to the Fundação Oswaldo Cruz (Rio de Janeiro, December/2009 and November/2011), the Museu de Zoologia de São Paulo (São Paulo, December/2009), the Natural History Museum (London, April/2010), and the Universidad Nacional de Colombia (Bogotá, September/2012).

Additional collections: American Entomological Institute, Gainesville (AEIC), Dr. David Wahl; American Museum of Natural History, New York (AMNH), Dr. James M. Carpenter; Natural History Museum, London (NHM), Dr. Gavin Broad; Estación de Biologia Chamela, San Patrício, México
(EBCC), Dr. Alicia Rodriguez-Palafox (in memorian), Dr. Ricardo Ayala-Barajas; Essig Museum, Berkeley (EMEC), Dr. Cheryl B. Barr; Florida State Collection of Arthropods, Gainesville (FSCA), Dr. J. Wiley; Museo Fairchild, Universidad de Panama (GBFM), Dr. Roberto Cambra T.; Instituto de Pesquisas Cientificas e Tecnológicas do Estado do Amapá, Macapá (IEPA), Sr. José Madson de Freitas Gama; Instituo Nacional de Biodiversidad, Santo Domingo (INBC), Dr. Jesus Ugalde and Dr. Jorge Carvajal Alfaro; Museo Nacional de Historia Natural del Paraguay, Asunción (INBP), Dr. John Kochalka and Bolivar Garcete-Barrett; Instituto Nacional de Pesquisas da Amazônia, Manaus (INPA), Dr. Augusto Henriques; Fundação Instituto Oswaldo Cruz, Rio de Janeiro (IOC), Dr. Marcio Félix; Museu de Zoologia da Universidade de São Paulo, São Paulo (MZSP), Dr. Carlos R. F. Brandão; Bohart Museum, University of California at Davis, Davis (UCDC), Dr. S. L. Heydon; Universidad Nacional de Colombia, Bogotá (ICN), Dr. Carlos Sarmiento; Smithsonian Institution, Washington (USNM), Dr. Ronald J. McGinley and Dr. David G. Furth; Zoologische Saamlung des Bayerischen Staates, Munich (ZSMC), Dr. Johannes Schuberth.

Material examined. A little more than 500 specimens are listed in this article, but considerably more were actually examined during visits to collections, especially to the Zikán Collection in Rio de Janeiro, where large nest series are often available. Types of nearly all specific and subspecific taxa were examined, with exception of $M$. mamirauae Raw, M. baconi Starr, M. basimacula guatemalensis Richards, and M. basimacula superpictus Richards.

Observations and drawings. The specimens were examined under dissecting stereomicroscopes, and drawings were made using a camera lucida adapted to ZEISS SV-11 equipment. Photographs were obtained using a LEICA DFC-420 camera adapted to a LEICA MZ-16 stereomicroscope. Male genitalia were not investigated since previous observations of Phi species (Silveira 2008) did not reveal significant interspecific variation. Terminology was the same utilized by Silveira (2008).

Measurements. The following measurements and ratios were obtained from data collected using a ZEISS SV-11 stereomicroscope with an ocular micrometer (see Fig. 1): FHH: height of head in frontal view (Fig. 1A); INTOW: distance between eyes at the level of ocular sinus (Fig. 1A); HCLP: height of clypeus (Fig. 1A); WCLP: width of clypeus (Fig. 1A); flm: length of free upper part of lateral margin of the clypeus (Fig. 1A); WCA: width of pronotal carina from above (Fig. 1B); LMS: length of mesoscutum (Fig. 1B); WMS: width of mesoscutum (Fig. 1B); HMP: height of mesopleuron from secondary spiracular entrance to articulation of mid coxa (Fig. 1E); Wng: length of fore wing (given in millimeters); LDIS: length of discal cell of fore wing; LSI: length of first metasomal segment from the ligament aperture to the apex; WSI: with of first metasomal segment at the apex; mWSI: width of first metasomal segment at the base; FHH/INTOW: aspect ratio of head in frontal view; H/WCL: aspect ratio of clypeus; flm/ HCL: ratio between the length of upper part of lateral margin 
and the height of clypeus; WCA/WMS: ratio between the width of pronotal carina and the width of mesoscutum; L/WMS: aspect ratio of mesoscutum; LDIS/HMP: ratio between the length of discal cell and height of mesopleuron; LSI/HMP: ratio between the length of first metasomal segment and height of mesopleuron; WSI/mWSI: ratio between two widths (apical/ basal) of first metasomal segment.

Geographic distributions. Data concerning distributions of the species (as inferred from the material actually examined) were obtained from the specimens labels and mapped with GIS software; geographic coordinates were obtained from the collection labels and by using the Google Earth program (version 5.2.1.1588). The distribution maps of the species were generated using ArcView 3.3.

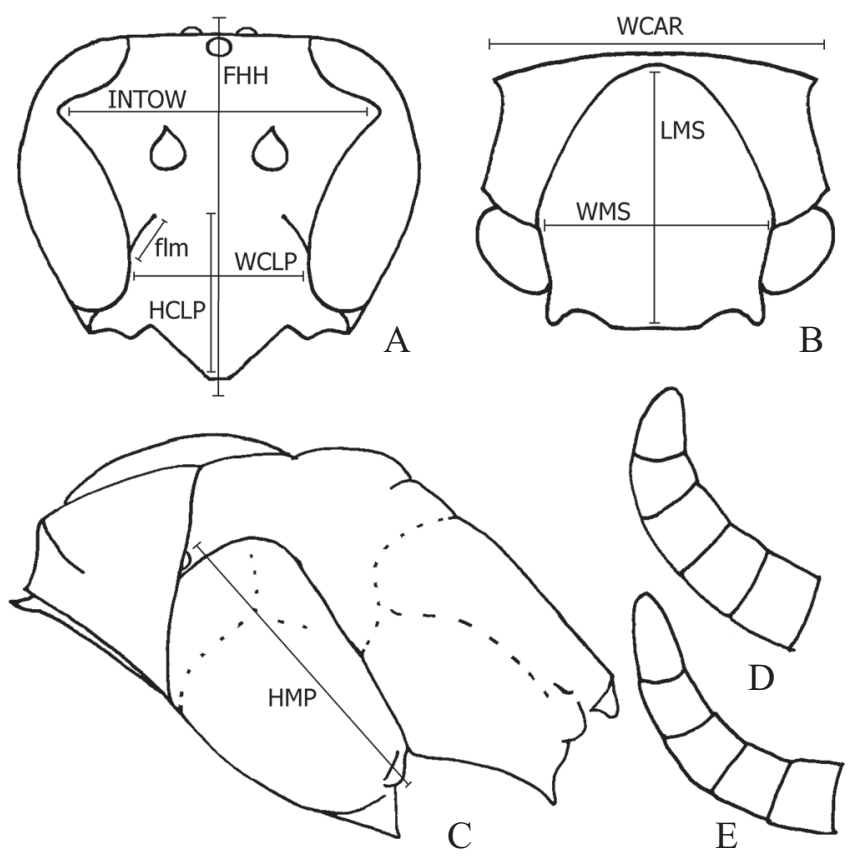

Fig. 1. Schematic drawings of the head (A) and thorax $(B, C)$ indicating measurements used in this work (FHH: height of head in frontal view; INTOW: distance between eyes at the level of ocular sinus; HCLP: height of clypeus; WCLP: width of clypeus; flm: length of free upper part of lateral margin of the clypeus; WCA: width of pronotal carina from above; LMS: length of mesoscutum; WMS: width of mesoscutum; HMP: height of mesopleuron from secondary spiracular entrance to articulation of mid coxa), and apex of the male antenna to show the aspect of the $13^{\text {th }}$ article in the alfkenii (D), and paraguayensis (E) groups.

\section{TAXONOMY}

New observations showed that contents of the group of "M. alfkenii and M.basimacula" as reported by Silveira (2008) were partly incorrect, as forms related to the names $M$. paraguayensis Zikán, M. bahiae Richards, M. aracatubaensis Zikán, and M.gilvus Zikán all share characteristics of the male's antenna and clypeus with the group of " $M$. infrastrigatus and M. costalimai" (as designated by Silveira, 2008). Furthermore, as proposed and discussed below, both the names $M$.

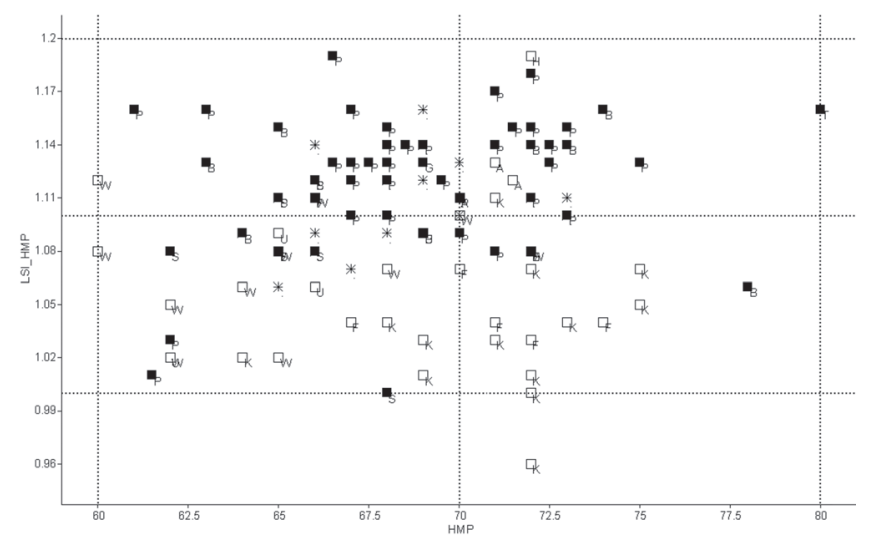

Fig. 2. Scatterplot of values of the ratio between the length of first metasomal segment and height of mesopleuron (LSI_HMP) against the values of the second variable (HMP; arbitrary scale). Species of the alfkenii group are represented by an open square (except for M.trinitatis, by an asterisk mark); species of the paraguayensis group are represented by a black square. Letters refer to species: A- M. awa, B- M. bahiae, E- M. embera, F- M. flavicornis, G- M. flavoniger, H- M. achagua, K- M. alfkenii, P- M. paraguayensis, S- M. suzannae, T- M. tayacaja, W- M. waunan.

infrastrigatus and $M$. costalimai are junior synonyms of $M$. paraguayensis, so that, from this point on, the second species group will be referred to as "M. paraguayensis and M. bahiae".

\section{Diagnosing studied groups from remaining Phi species}

The two species groups here considered are in fact very similar, and share most characters with a third group referred by Silveira (2008) as the M. mexicanus group, which also includes M. angulatus Richards, "M. angulatus morph ictericus" Richards, M. costaricensis Richards, M. mexicanus cubicola Richards, M. phthisicus (F.), and M. cubensis (de Saussure). In these groups, the males show the antennal apex short and the $13^{\text {th }}$ article in particular is quite short, never more than 2.5 times longer than broad (Figs. 1 D, E). In all other species of $P h i$, the male antennal apex is slender, either hooked or longer and coiled (see Silveira 2008). However, in the mexicanus group the metanotum is distinctly more convex and the hairs on the head and propodeum tend to be longer. The species are distributed through southeastern North America (coastal areas and islands), Central America and the Caribbean, with $M$. angulatus also occurring in northwestern South America.

Species of the alfkenii and paraguayensis groups can be differentiated from other Phi species by the following combination of characters: (1) apex of male antenna with articles generally broad, $13^{\text {th }}$ at most 2.5 times as long as wide at base; (2) male clypeus never presenting abundant silvery appressed pubescence; (3) pronotal secondary margin sharp and projecting over anteromedian lamella; (4) pronotal carina not completely absent at center, its course still perceptible there; (5) female clypeus with apex narrowly truncate; (6) metanotum noticeably flattened; (7) body hairs shorter and less conspicuous; (8) first metasomal segment shorter than hind femur + trochanter, never exceedingly slender. The joint distributions of the species range from Central México to North of Argentina (see Fig. 7). 


\section{Identification Key (for females, except as noted)}

1. Female clypeus more extensively in contact with eye, free upper part of lateral margin short (Figs. 1A; 3B; 4A), hardly more than 0.3 times the clypeus height at middle; apex of male antenna with articles very broad and short (Fig. 1D), $13^{\text {th }}$ about 1.5 times as long as wide at base; male clypeus clearly touching eyes; first metasomal segment relatively short, hardly longer than 1.1 times height of mesopleuron; color yellow with black or brown marks (group of alfkenii and basimacula) 2

1 '. Female clypeus less extensively in contact with eye, free upper part of lateral margin longer (Figs. 1A; 3A), normally more than 0.33 times clypeus height at middle; apex of male antenna with $13^{\text {th }}$ article 2-2.5 times as long as wide at base (Fig. 1E); male clypeus narrowly separated from eyes; first metasomal segment normally longer than 1.1 times height of mesopleuron (group of paraguayensis and bahiae) 13

2. Subalar plate largely black or dark brown (Fig. 3D); propodeum with distinct black or brown marks, at least a central stripe and paired dorsal and ventral triangular marks ................ 3

2'. Subalar plate yellow (Fig. 3C), without noticeable dark parts; propodeum yellow, at most with central line or lateral ventral orifices darker, occipital band always strongly reduced on its posterior lower parts

7

3. Larger inner claw of hind tarsus with apex broad and tending to a round contour (Fig.5F); occipital band largely reduced on its posterior lower parts, dark marks on pronotum and mesoscutum normally developed; metasomal segment 1 unusually long, more than 1.1 times height of mesopleuron, distal campanula elongate; Colombia (Meta; male unknown)... M. achagua sp. nov. (Fig. 3E)

3'. Larger inner claw of hind tarsus with apex narrowly pointed (Fig. 5G); occipital band not reduced on its posterior lower parts; metasomal segment 1 short, normally less than 1.1 times height of mesopleuron

.. 4

4. Antennal flagellum entirely light orange or yellowish brown (Fig. 3B, D); supra clypeal plate normally without noticeable brown marks, at most with a discontinuous faint mark on interantennal area; fore wing longer, length of discal cell more than 2.5 times the height of mesopleuron ..... 5

4'. Antennal flagellum darker brown or black at least basally (Fig. 4A, 5A); interantennal area usually with a strong continuous brown horizontal bar

5. Antennal scape and pedicel light yellowish brown, at most with rather diffuse distal mark above, more often with the same color of flagellum; transition between dark and pale colors more gradual ......... M. alfkenii (Ducke) (Fig. 3B)

5'. Antennal scape and pedicel distinctly black above, contrasting with light orange or yellowish flagellum; transition between dark and pale colors very sharp, at least on head and thorax M. flavicornis Zikán (Fig. 3D)

6. Scape, pedicel and first flagellomere black above, distinctly contrasting with lighter distal part of flagellum, second metasomal sternum nearly always with a tridentate dark mark ..................... M. basimacula (Cameron) (Fig. 4A)

6'. Dorsum of antennal flagellum brown; if scape, pedicel and first flagellomere darker, then transition more gradual to distal articles; second metasomal sternum normally without a tridentate dark mark; last segment of hind tarsus brownish above; México, Panama, and Colombia (west coast) M. waunan sp. nov. (Fig. 5A)

7. Larger inner claw of hind tarsus with apex broad and tending to a round contour (Fig. 5F); brown frontal mark blurred, contour poorly defined, metasomal terga testaceous without distal yellow bands; Panama (male unknown) ......................... M. embera sp. nov. (Fig. 3F)

7'. Larger inner claw of hind tarsus with apex narrowly pointed (Fig. 5G)

.. 8

8. Antenna quite dark, black or dark brown above, lighter only distally beneath; pronotal carina never exceedingly prominent at sides

9

8 '. At least antennal flagellum light orange or (at most) reddish brown, scape concolor or with a distal diffuse mark (Figs. 3C)

9. Metasomal terga testaceous with narrow distal yellow bands, sometimes widening at sides; Colombia (eastern range) ............................................... muisca sp. nov.

9'. Metasomal terga dark brown with narrow distal yellow bands; first metasomal tergum very narrow at apex; Guyana (Fig. 4C, D)

M. arawak sp. nov.

10. At least metasomal terga 3 to 5 dark brown with wide distal yellow bands, marks on mesoscutum definitely of a darker brown color (Fig. 4B) ........................................ 11

10'. Metasomal terga testaceous with yellow bands (sometimes inconspicuous), dark marks on head and thorax light reddish brown, often blurred (Figs. 4E, F) ................ 12

11. Nest with eccentric peduncle (Figs. 3C, 4B) .... M. trinitatis Richards n. stat.

11 '. Nest with centric peduncle and roughly circular comb (Fig. 6B), only recorded from Trinidad .. M. baconi Starr

12. Pronotal carina prominent at sides, often with more or less distinct lobes; metasomal tergum 1 wide at apex, its width about 0.44 of length; northern Colombia (Fig. 4F) M. uniformis sp. nov.

12'. Pronotal carina never exceedingly prominent at sides; metasomal tergum 1 not noticeably widened at apex, width about 0.4 of length; western Ecuador (Fig. 4E)

M. awa sp. nov.

13. Larger inner claw of hind tarsus with apex acute; propodeal cavity unusually deep for this group; largely black with yellow brown clypeus and legs; relatively large species, wing-length $11 \mathrm{~mm}$; Peru (Huancavelica; male unknown) (Fig. 5B)

M. tayacaja sp. nov.

13'. Larger inner claw of hind tarsus with apex just narrowly pointed, not really acute (see Fig. 5G); color variable, size generally a little smaller ........................................ 14 
14. Yellow species with all the metasomal segments entirely black, unbanded M. flavoniger Zikán

14'. Color variable, if metasoma is black, then the entire insect is black 15

15. Mainly yellow wasps with metasomal terga testaceous, hardly showing banded patterns; mesopleuron yellow, rarely with a small ventral brown spot; propodeum yellow with central black or brown stripe and lateral maculation including paired dorsal triangles of light brown color (sometimes propodeum almost totally yellow) ..... M. bahiae Richards

15 '. Extremely variable in color, from richly patterned to almost entirely black wasps; metasomal segments often showing well-developed banded patterns (Fig. 5D), but sometimes with terga 3-6 black, unbanded (Fig. 5C), or the whole insect black; mesopleuron and propodeum similarly variable, sometimes completely yellow, but more normally with dark marks

16

16. Pronotal carina very salient at sides

M. catharinaensis Zikán

16'. Pronotal carina normal, lower, not strongly projecting at sides

17. Pronotum with humeral region less projecting, nearly rounded, carina very low, almost without a lamellar portion; wings very short, length of discal cell of fore wing less than 2.0 times the height of mesopleuron; color black or dark brown, clypeus with a ventral clearly delimited "U-shaped" yellow mark, pleuron, propodeum and first metasomal segment lighter brown, mid and hind legs light brown without yellow marks, all tarsal segments dark; Brazil (Pará) (Fig. 5E) ................... M. suzannae sp. nov.

17'. Humeral region angularly produced, pronotal carina with distinct lamellar portion; wings normally elongated, length of discal cell of fore wing more than 2.0 times the height of mesopleuron; color variable, if black or dark brown, then mid and hind legs with light marks (included tarsal segments), clypeus if yellow marked, then mark not " $U$ shaped" (Fig. 5C, D) ....

M. paraguayensis Zikán

\section{Group of M. alfkenii and basimacula}

Refers to a group of 12 known species with the characters given in couplet 1 of the key. Contrary to Silveira (2008), forms referred by Richards (1978) to the names $M$. paraguayensis and M. bahiae (and M. aracatubaensis, and M. gilvus) do not pertain here.

\section{Mischocyttarus alfkenii (Ducke, 1904)}

(Fig. 3B)

Megacanthopus alfkenii Ducke, 1904: 362; Lectotype: Female, Brazil, AP, Rio Villanova (MZSP); designated by Richards (1978) [examined].

Mischocyttarus alfkenii: Ducke, 1905a: 22; 1905b: 688, pl. 4, figs. 24a, b; 1907: 188; Richards, 1945: 395, figs. 66, 68 (in part; except varieties bahiae Richards, excrucians Richards, trinitatis Richards, and Zikánii Richards); 1978: 343, 344 (in part; except subspecies excrucians and trinitatis); Silveira, 2008: 516, 518, 540, 546, fig. 88, table ii; O’Connor et al. 2011: 447(misidentification).
Mischocyttarus japuraensis Zikán, 1949: 147; synonymy by Richards (1978). Holotype Female, Brazil, AM, R. Japura (MZSP 17.706) [examined].

Mischocyttarus mamirauae Raw, 1996: 3. Holotype Female and "Allotype" (author's private collection); Paratypes: USNM; INPA (not found); MPEG (not found) and Oxford University Museum; N. syn.

Female: length of fore wing 10-11 mm; clypeus wider than high, H/WCLP about 0.93 , apex narrowly truncate, clypeus more extensively in contact with eye, free upper part of lateral margin short, hardly more than 0.3 times the clypeus height at middle; malar space narrow; tentorial pit a little closer to eye margin than to antennal socket; oceli as in an equilateral triangle; occiput rounded, carina absent; gena considerably narrower than the upper lobe of the eye; pronotum with lateral fovea, central part of the anterior margin of pronotum with the lamella wide but not reflexed, region immediately behind produced into a secondary margin which is acute and projecting over the lamella; humeral angle well developed, carina salient at sides but not forming true lobes, mostly reduced at center, not lamellate there, nearly straight, not really reflexed at sides, with a very narrow translucent lamellar portion, total width of carina about 1.1 to 1.2 times larger than that of mesoscutum (wider in larger specimens), sides of the pronotum as seen from above not noticeably converging; mesoscutum about as long as wide, L/WMS around 1.0; fore wing very elongated, LDIS/HMP about 2.5; inner claw of hind tarsus with the apex narrowly pointed, but not acute; propodeum with median furrow rather shallow and narrow, developed on $2 / 3$ of the length of propodeal dorsum, propodeal valve very narrow, with a subquadrate outline; first segment of metasoma evidently short, LSI/HMP only about 1.03 , about 2.5 times wider at the apex than at the basal petiole, spiracles not noticeably prominent.

Sculpture: indistinct, disk of clypeus mostly with shallow small sized punctures, larger ones rare and inconspicuous, area close to the ventral margin finely reticulate and shining, with a few isolated large punctures; mesopleuron with shallow fine punctures, integument rather shining.

Vestiture: eyes bare; hairs beneath gena only moderately long.

Color: yellow; antenna light orange yellow, except (sometimes) for an indistinct brownish dorsal mark on scape distally, and for the yellow underside of scape and pedicel; sometimes a very indistinct and narrow streak on interantennal area, bifid frontal mark with anterior arms truncate or tapering, basally with winglets beside posterior ocelli, and posteriorly connected to an occipital band in which a lower median"window" is formed, laterally with two narrow extensions reaching the composite eyes (sometimes bifurcating and connecting to the basal winglets and thus enclosing two small spots), variably wide mark on pronotal anterior face (often lighter), moderately large humeral mark (often lighter), three wide stripes on mesoscutum coalescing at the extremities, opposite anterior and posterior triangular (more often) scutellar marks connected by a median line, posterior half or more of metanotum, wide median stripe and paired triangular anterior and posterior marks on propodeum, the 
latter pair of marks continuing anteriorly into lateral lines (the whole pattern producing more or less clear lateral Vshaped yellow marks), mesepisternal and scrobal sulci linked to large spot on subalar area, dark brown or black; two stripes on mid coxa, two or three on hindcoxa, large elongated marks on dorsum of mid and hind femora and tibiae, distal segments of mid and hind tarsi, most of metasomal terga proximally, light testaceous brown (metasoma tergal pattern with distal yellow bands); all metasoma sterna yellow; wing hyaline with yellow brown veins.

Male: length of fore wing $10 \mathrm{~mm}$; clypeus touching eyes, a little wider than high, H/WCLP 0.93, ventral angle obtuse, apex narrowly rounded; antenna with the scape relatively shorter and wider, ventral surface of the flagellum with tyloids reduced or fragmented, apex of the antenna very short and broad, antennomere 13 about 1.5 times longer than wide; clypeus without very conspicuous or shining pubescence; hairs on frons and gena behind not very different of the condition in female.

Color: similar to female; occipital band more strongly reduced.

Variation: some variation exists in de degree of lateral prominence of the pronotal carina (that is probably related to size variation) and width of the first metasomal tergum. Some specimens have the brown marks on propodeum and antennal scape a little darker and more extensive.

Nest: the nest has been shown by Ducke (1905b) in photographs of two exemplars presenting the gymnodomous stelocyttarous architecture usual for the genus. The photographs demonstrate variation in peduncle position and comb shape, with a small exemplar from one of the type localities (Amapá; Fig. 24b) having a strongly eccentric peduncle and more elongated comb, while another much larger nest from western Amazon (Rio Japurá; Fig. 24a) shows a nearly perfectly circular comb and (inferred) centric peduncle.

Distribution: Brazil: Amazonas, Amapá, Pará, Maranhão; Peru: Loreto.

Remarks: Ducke's specimens from Iquitos (mentioned in the author's 1907 paper) could not be found in the Museu Goeldi. There is some possibility that they could be $M$. flavicornis, which was recorded from Acre (Richards, 1978) and western Amazonas, Rio Juruá (see below). Mischocyttarus excrucians and $M$. trinitatis described as varieties by Richards (1945) and treated as subspecies by Richards (1978) are not the same species as M. alfkenii (see below). All of the references made by O'Connor et al.(2011) to M. alfkenii are either incorrect (Trinidad specimens), or dubious (Venezuela specimen; from Arévalo et al., 2004). Mischocyttarus mamirauae was described by Raw (1996) as an Amazonian representative of the " $M$. cassununga group". However, the described shape of the male antenna and other characters clearly show that this form belongs instead to the alfkenii and basimacula group (see also Silveira 2008). While types could not be examined, specimens collected in Mamirauá by Gorayeb \& Silveira (MPEG) unequivocally indicate that $M$. mamirauae Raw is a junior synonym of M. alfkenii (Ducke).
Examined Material. Brazil: Amazonas, Mamirauá-Várzea, 20.ix.1993 (female, 3 males), I. S. Gorayeb \& O.T. Silveira, R. Japurá, 16.ix.1904 (female), 21.ix.1904 (4 females, 4 males), Tefé, 25.ix.1904 (male), A. Ducke; Amapá, R. Vilanova, 26.x.1900 (female, Paralectotype), A. Ducke; Pará, Óbidos, 1904 (female), 15.i.1904 (female), 5.i.1905 (female), 18.v.1905 (male), 23.ix.1913 (male) A. Ducke; Serra Norte, Salobo, 18-21.x.1984, Armadilha Malaise (female), Fofoca, 29.x.1984 (male), M. Zanuto; Tucuruí, 6.vii.1978 (female), P. Tadeu; 10. iii. 1979 (4 females, 3 males), W. Overal; 5.vii.1980? (female), W. França; Maranhão, Buriticupu, 30.ix.1978 (female), M. F. Torres (MPEG).

\section{Mischocyttarus flavicornis Zikán, 1935}

(Figs. 3D)

Mischocyttarus flavicornis Zikán, 1935: 168; Lectotype: Female, Brazil, Goiás, Santa Rita da Anta (MZSP); designated by Richards (1978) [examined].

Mischocyttarus flavicornis: Zikán, 1949: 153, figs. 94, 237, 238, 382; Richards, 1978: 340; Silveira, 2008: 516, 540.

Mischocyttarus basimacula var. flavicornis: Richards, 1945: 394.

Mischocyttarus flavicornis race nigricornis Zikán, 1949: 154. Lectotype Male, Peru, Cusco, R. Urubamba (IOC); designated by Richards (1978) [examined]; N. syn.

Mischocyttarus flavicornis var. rufescens Zikán, 1949: 155. Synonymy by Richards (1978). Lectotype Male, Peru, Junin, Satipo (IOC); designated by Richards (1978) [examined].

Mischocyttarus alfkenii var. excrucians Richards, 1945: 396. Holotype Female, Colombia, Meta, Restrepo (MCZC), Paratype Female, Surinam, R. Surinam, Saint Barbara Plantation, 15.iv.1927 (NHM) [examined]; N. syn. Mischocyttarus alfkenii excrucians: Richards, 1978: 344 (misidentification).

Female: morphology similar to the preceding species; length of fore wing $10.5-11.5 \mathrm{~mm}$; clypeus wider than high, H/WCLP about 0.92 ; total width of pronotal carina about 1.1 to 1.2 times larger than that of mesoscutum (wider in larger specimens); mesoscutum about as long as wide, L/WMS around 1.0; fore wing very elongated, LDIS/HMP about 2.5 to 2.7 ; inner claw of hind tarsus with the apex narrowly pointed, but not quite acute; propodeum with median furrow rather shallow and narrow, developed on $2 / 3$ of the length of propodeal dorsum, propodeal valve narrow, with a subquadrate outline; first segment of metasoma evidently short, LSI/HMP only about 1.05, about 2.6 times wider at the apex (than at the basal petiole), spiracles not noticeably prominent.

Sculpture: indistinct, disk of clypeus mostly with shallow small sized punctures, larger ones rare and inconspicuous, area close to the ventral margin finely reticulate and shining, with a few isolated large punctures; mesopleuron with shallow fine punctures, integument rather shining.

Vestiture: eyes bare; hairs beneath gena only moderately long.

Color: yellow with sharply contrasting black marks on head and thorax, brown on metasoma; antenna light orange yellow, except for a distinct sharply defined black dorsal mark on scape and pedicel, and for the yellow underside of scape and pedicel; sometimes a very indistinct and narrow streak on interantennal area, bifid frontal mark with anterior arms truncate (more often) or tapering, basally with winglets beside posterior ocelli, and posteriorly connected to an occipital band in which a lower median window (small) is formed, laterally with two narrow extensions reaching the composite 

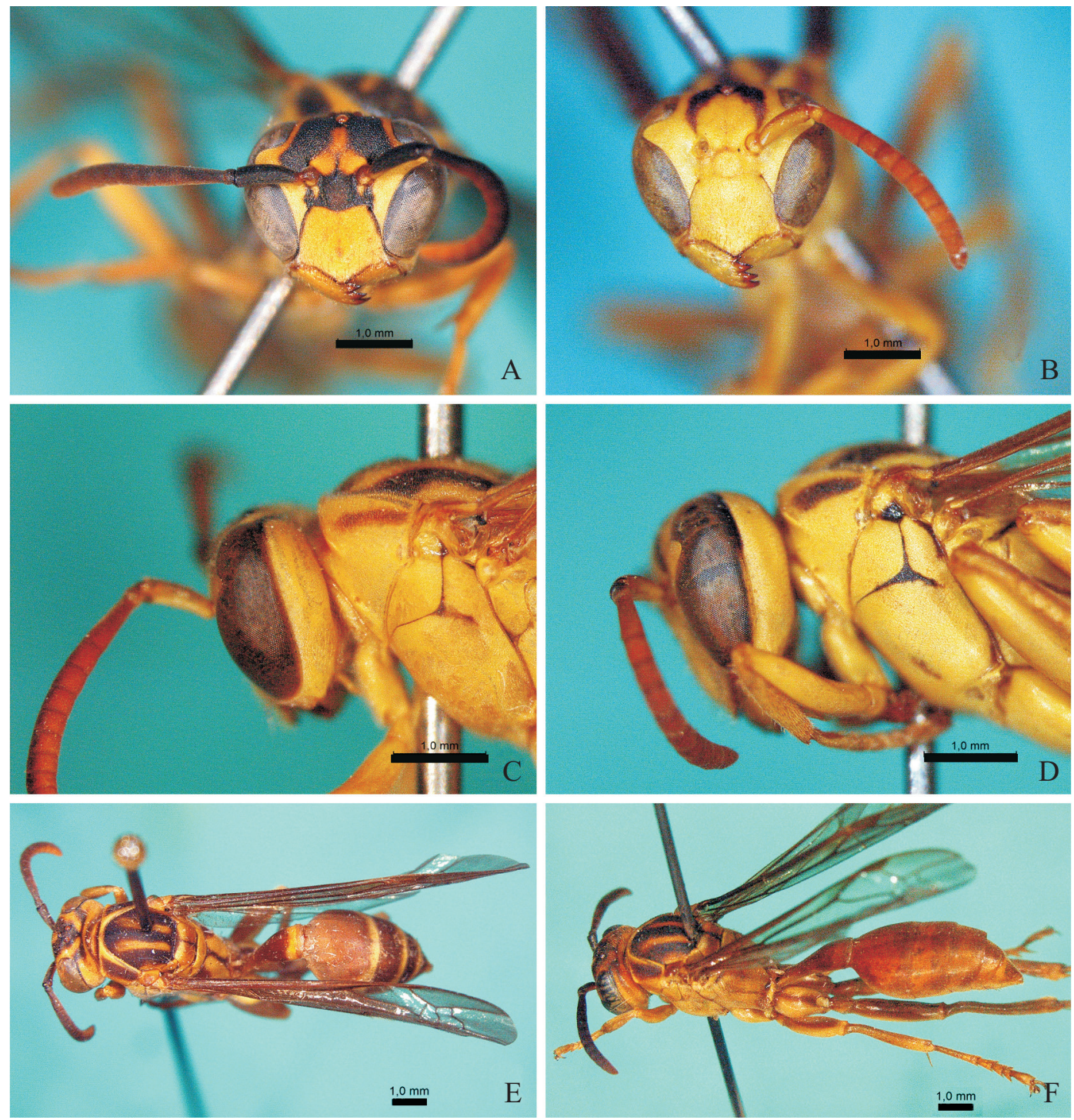

Fig. 3. A-B: frontal view of head of M. paraguayensis (A) and M. alfkenii (B); C-D: lateral detail of head and thorax of M. trinitatis (C) and M. flavicornis (D); E-F: general views of M. achagua sp. nov. (E) and M. embera sp. nov. (F); scale bar measures $1 \mathrm{~mm}$.

eyes, small mark on pronotal anterior face (often lighter), moderately large humeral mark (sometimes lighter), three wide stripes on mesoscutum coalescing at the extremities, opposite anterior and posterior triangular (more often) scutellar marks connected by a median line, posterior half or more of metanotum, wide median stripe and paired triangular anterior and posterior marks on propodeum, the latter pair of marks continuing anteriorly into lateral lines (the whole pattern producing more or less clear lateral V-shaped yellow marks), mesepisternal and scrobal sulci linked to large spot on subalar area, black; two stripes on mid coxa, two or three on hind coxa, large elongated marks on dorsum of mid and hind femora and tibiae, distal segments of mid and hind tarsi, most of metasomal terga proximally, light testaceous brown (metasomal tergal pattern with wide distal yellow bands); all metasomal sterna yellow; wing membrane hyaline with pale yellowish hairs, and yellowish brown veins.
Male: length of fore wing $11 \mathrm{~mm}$; clypeus touching eyes, a little wider than high, H/WCLP 0.93 , ventral angle obtuse, apex narrowly rounded; ventral surface of the antennal flagellum with tyloids reduced or fragmented, apex of the antenna very short and broad, antennomere 13 about 1.5 times longer than wide; clypeus without very conspicuous or shining pubescence; hairs on frons and gena beneath not very different of the condition in female.

Color: similar to female; arms of frontal mark wider.

Nest: the nest has been described by Richards (1978: 341) based upon two exemplars from Brazil, Mato Grosso, "Base Camp" (completed cell $14.0 \times 3.2 \mathrm{~mm}$ ), and from Peru, Huanúco, Tingo Maria (completed cell 13.0 x 3.0 mm). The peduncle may be centric or eccentric.

Distribution: Colombia: Nariño [?], Meta and Putumayo (as excrucians in Richards, 1978); Guyana and Surinam (as excrucians); Brazil: Acre (as excrucians), Amazonas, Pará, 
Maranhão, Goiás, Mato Grosso, Rondônia; Bolivia: Beni; Ecuador: Manabi [?]; Peru: Cusco, Junin, Huánuco, Pasco, Loreto.

Remarks: In spite of its very wide distribution, this species is remarkably uniform in morphology and coloration. The very small differences in color tonality do not seem to justify recognizing $M$. flavicornis nigricornis Zikán (or $M$. flavicornis rufescens Zikán) as subspecies, as partially sustained by Richards (1978). Mischocyttarus alfkenii excrucians Richards, 1945 is a junior synonym of $M$. flavicornis based on evidence apparent in Richards's description, and by examination of specimens from Colombia, Meta, and a paratype from Surinam (Surinam R., Saint Barbara Plantation, 15.iv.1927, NHM). The darker and sharply defined marks, including those on the antennal scape and pedicel, typically observed in M. flavicornis are unequivocal evidence of synonymy. The lighter tones of those marks as reported by Richards (1978) in specimens from the Pacific coast of Colombia and Ecuador make these records uncertain. Examination of material identified by this author deposited in the NHM led to the conclusion that he confounded this species with $M$. waunan sp. nov. Nevertheless, records of $M$. flavicornis from southern Pará (Conceição do Araguaia) and Maranhão (Imperatriz) seem to be consistent.

Examined Material. Colombia: Meta, San Juan de Arama, 8.i.1992 (female), San Juan de Arama, Vda. Morrobello 1150m, 11.i.1992 (female), A. Polania (ICN), La Macarena, 29.x-7.xi. 1976 (female), 11.xi.1976 (female), 20-29.xi. 1976 (female), M. Cooper (NHM); Surinam, R. Surinam, Saint Barbara Plantation, 15.iv.1927 (female; Paratype of var. excrucians) (NHM); Brazil: Amazonas, Ipixuna, Rio Liberdade, Estirão da Preta, 11-15.v.2011 (3 females), J. A. Rafael, J. T. Câmara, R. F. Silva, A. Somavilla, A. Agudelo (MPEG); Goiás, female (no. 17.105; IOC); Mato Grosso, Chapada dos Guimarães, 11.xi.1982 (2 females); Rondônia, Ji-Paraná, 15.viii.1984 (female), R. B. Neto (MPEG); Bolivia: Beni, Rio Beni, 30 km N Buenaventura, 5.xi.1981 note 54 (3 females, 1 male), M. Cooper (NHM); Peru: Cusco, Santa Ana, Rio Urubamba 800m, 1.xii.1940 (female Paralectoype of nigricornis), Weyrauch; Junin, Sátipo, 31.v.1940 (female; Paralectotype of var. rufescens), 17.xi.1940 (female), 24.ix.1940 (female), Paprzycki (IOC).

\section{Mischocyttarus basimacula (Cameron, 1906)}

\section{(Fig. 4A)}

Polybia basimacula Cameron, 1906: 150; Lectotype: Female, Belize (NHM); designated by Richards (1945) [examined].

Mischocyttarus basimacula: Richards, 1945: 391, figs. 65, 67; 1978: 342; Zikán, 1949: 158, figs. 96, 97, 239, 240; Silveira, 2008: 516, 518, 540, 546, fig. 70, table ii.

Mischocyttarus basimacula var. guatemalensis Richards, 1945: 393. Holotype Female, Guatemala, Solola (MCZC) [not examined]; synonymy by Richards (1978).

Mischocyttarus basimacula var. superpictus Richards, 1945: 393. Holotype Female, Colombia, Cauca, Rio Porce, near Porcecito (MCZC) [not examined]; N. syn.

Mischocyttarus basimacula superpictus: Richards, 1978: 343 (misidentification).

Female: morphology similar to the preceding species; length of fore wing 8.5-10.5 mm; clypeus wider than high, H/WCLP about 0.94 , apex narrowly truncate, clypeus more extensively in contact with eye, free upper part of lateral margin short, hardly more than 0.3 times the clypeus height at middle; humeral angle well developed, carina variably salient at sides but not forming true lobes, mostly reduced at center, not lamellate there, nearly straight, not really reflexed at sides, with a very narrow translucent lamellar portion, total width of carina about 1.05 to 1.15 times larger than that of mesoscutum; mesoscutum slightly longer than wide, L/ WMS about 1.04; fore wing well elongated, LDIS/HMP from 2.3 to 2.6 ; inner claw of hind tarsus with the apex narrowly pointed, but not acute; first segment of metasoma evidently short, LSI/HMP only about 1.07, about 2.5 times wider at the apex than at the basal petiole, spiracles not noticeably prominent.

Sculpture: indistinct, disk of clypeus mostly with shallow small sized punctures, larger ones rare and inconspicuous, area close to the ventral margin finely reticulate and shining, with a few isolated large punctures; mesopleuron with shallow fine punctures, integument rather shining.

Vestiture: eyes bare; hairs beneath gena only moderately long.

Color: yellow with sharply contrasting black or dark brown marks; antennal scape and pedicel black above, yellow beneath; first flagellomere black above, contrasting with lighter distal articles, flagellum light orange yellow beneath; supraclypeal plate and interantennal area always with some maculation, sometime almost entirely black enclosing a pale spot; upper segment of lateral margin of clypeus tinged of black; bifid frontal mark with anterior arms truncate (sometime widened and entering the ocular sinus), basally with short winglets beside posterior ocelli, and posteriorly connected to a broad occipital band in which a small median window may be formed, laterally with two extensions reaching the composite eyes, a wide mark on pronotal anterior face, moderately large humeral mark (sometimes lighter), three stripes on mesoscutum coalescing at the extremities, opposite anterior and posterior triangular (more often) scutellar marks connected by a median line, posterior margin of metanotum, wide median stripe and paired anterior and posterior marks on propodeum, the latter pair of marks continuing anteriorly into lateral lines (the whole pattern producing more or less clear lateral V-shaped yellow marks), mesepisternal and scrobal sulci broadly, connected to large spot on subalar area, ventral spot on mesopleuron, mark along the suture between meso and metapleura, posterior spot on metapleura, black or dark brown; two stripes on mid coxa, three on hind coxa; mid and hind trochanters mostly posteriorly, small elongated marks on dorsum of fore femur and tibia; large elongated marks on dorsum of mid and hind femora and tibiae, basal segment of mid and hind tarsi, brown; metasomal terga 1-5 proximally black or dark brown (pattern with very wide distal yellow bands), apparent distal parts of tergum 6 yellow; metasomal sternum 1 with lighter brown maculation, sternum 2 nearly always with a basal (sometimes tridentate) dark brown mark, visible remaining sterna yellow; wing membrane hyaline with pale yellowish hairs, and yellowish brown veins. 

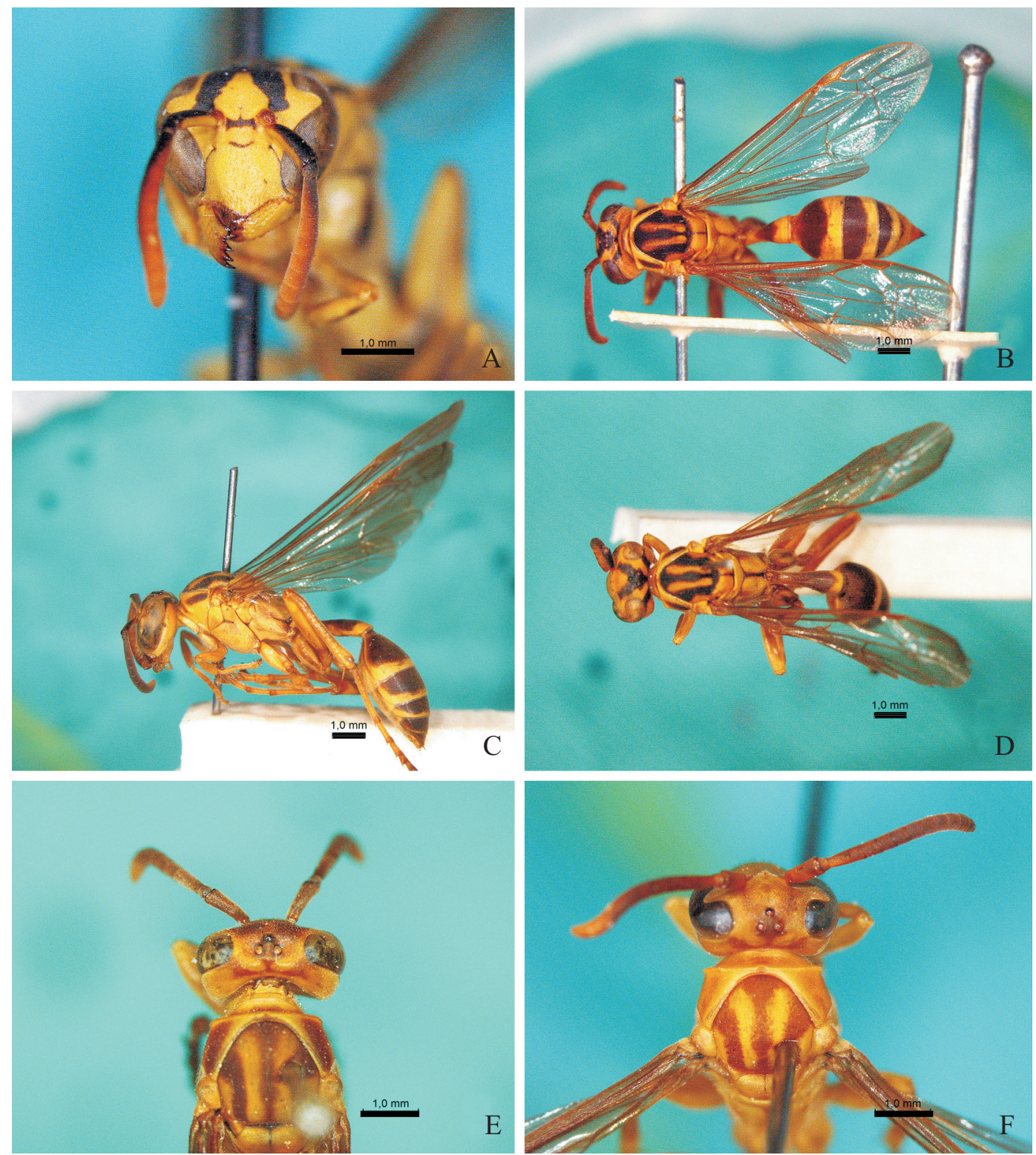

Fig. 4. A: frontal view of head of M. basimacula; B-D: general views of M. trinitatis (B, dorsal), and M. arawak (C, lateral; D, dorsal); E-F: dorsal view of head and thorax of M. awa sp. nov. (E) and M. uniformis sp. nov. (F).

Male: length of fore wing $7-10.5 \mathrm{~mm}$; clypeus touching eyes, wider than high, H/WCLP about 0.90 , ventral angle obtuse, apex narrowly rounded; antennal flagellum with tyloids reduced or fragmented, apex of the antenna very short and broad, antennomere 13 about 1.5 times longer than wide; clypeus without very conspicuous or shining pubescence; hairs on frons and gena beneath not very different of the condition in female.

Color: similar to female.

Nest: the nest has been described by Richards (1945) and figured in Rau (1933). The peduncle may be centric or eccentric.

Distribution: México: San Luis Potosi, Tabasco, Veracruz, Oaxaca, Yucatán; Belize; Guatemala; El Salvador; Honduras; Nicaragua; Costa Rica; Panama; Colombia: Antioquia,
Boyacá, Cundinamarca, Magdalena, Tolima, Valle?; Venezuela: Zulia; Ecuador: Pichincha.

Remarks: Records of the species in Richards (1978) from the Colombian departments of Valle and Nariño refer to another species, here described as M. waunan sp. nov. However, the occurrence of M. basimacula in Colombian "West coast" seems to be granted as inferred from its occurrence in Pichincha, Ecuador (FSCA). A number of specimens of the form described by Richards (1945) as variety superpictus, and subsequently (1978) treated as a subspecies, were examined from Colombia, Antioquia (Porce and San Luis), Cundinamarca and Tolima (UCDC, ICN). They seem to represent only a color variant. Specimens presenting the more typical lighter pattern were also found from Colombia, Antioquia (MPEG), Magdalena (INC) and Venezuela, Zulia (UCDC). 
Examined Material. México: Veracruz, Fortin de Las Flores, 24.xii.1963 (9 females), C. A. Toschi \& M. J. Tauber, Cordoba, 20.vi.1966 (female, male), 28.vi.1966 (female), 25.viii.1966 (3 females, 1 male), J. S. Buckett, M. R. \& R. C. Gardner (UCDC); Oaxaca, $85.5 \mathrm{~km} \mathrm{SW}$ of Tuxtepec, 21.x.1962 (male), H \& M Townes (AEIC); Yucatán (female, no date), G. F. Gaumer (UCDC); Chichen Itza, 18.iv.1962 (5 females), F. D. Parker \& L. A. Stange, 22.iv.1965 (10 females), C. L. Bolton, 9.viii.1968 (2 females), R. Albert (FSCA); Belize: (female; no date and collector) (MPEG); Guatemala: Guatemala City, 5.x.1979 (female), E. Aguilar (UCDC); Rabinal, 1.iii.1965 (female), G. S. O. O’Neal (UCDC); Mixco, 31 .iii.1994 (female, male), L. Marquez (FSCA); El Salvador: Quezaltepec, 2.vii.1961 (male), $2.5 \mathrm{mi} \mathrm{W}$ Quezaltepec, 27.vi.1961 (15 females, 3 males), M. E. Irwin; 3.vii.1963 (2 females), D. Cavagnaro \& M.E. Irwin (UCDC); Honduras: Zamorano, 27.iv-5.v. 1964 (female) (UCDC); $30 \mathrm{~km}$ E Tegucigalpa, 24.iv. 1985 (20 females, 9 males), F. Morazon (FSCA); Costa Rica: Golfito, 11.vii.1957 (female), A. Menke; PU Parmita, 20.ii. 1976 (2 females), R. M. Bohart, Turrialba, 1.vii.1963 (female), D. Cavagnaro \& M.E. Irwin (UCDC); Escazú, 21.v.1987 (female), 23.v.1987 (female), H \& M Townes (AEIC); Panama: Lino, 800m (4 females; no date and collector) (MPEG); 20 km S Sta. Fe Los Huyos (Rivera R. Sta. Maria/Veraguas), 9.viii.1987 (female), R. Cambra (GBFM); Colombia: Antioquia, Frontino, PNN Orquídeas, Caballo Venados, 920m, 8.iv.1996 (female), J. Vargas (MPEG), same data (2 females, nest) (ICN); Porce, 1000m, 1.viii.1983 (female), San Luis, 1075m, 1.viii.1983 (female), R. Vélez-Angel (UCDC); Cundinamarca, Anapoima, 7.v.1978 (female), Chia, 12.v.2001 (female), Facatativá, 17.iv.1993 (female), A. Aranguren, Fusagasugá 1720m, 12.ix.2004, (female), C. Aucique, C. Puentes; Girardot, 1.ix.1981 (female); San José, 4.xii.2004 (female), Cubillos coll.; Ubalá Vda. El Puerto, 20.i.1998 (female), M. Garcia; Utica, 9.vi.1972 (female), Rabeya coll.; Villeta, 10.ii.2003 (female), G. Herrera; Magdalena, Sierra Nevada de Santa Marta, Rio Perdido 550m, 17.xi.1995 (female), C. Sarmiento; Tolima, La Vega, 12.iii.1994 (female), E. Benitez, Libano, 16.v.1976 (female), R. Henao (ICN); Venezuela: Zulia, Maracaibo, Caño Colorado, 27.vi.1979 (female), Brooks, Grigarick, McLaughlin, Schuster (UCDC); Ecuador: Pichincha, Tinalandia ca. Santo Domingo de Los Colorados, 21-22.vi.1982 (female), C. Porter, T. O’Neill; $12 \mathrm{~km}$ E Sto. Domingo de Los Colorados 2500ft, 11-17.v.1986 (male), J. E. Eger; 5-10.12.1993 700m (female), J. B. Heppner (FSCA).

\section{Mischocyttarus waunan sp. nov.}

(Fig. 5A)

Mischocyttarus basimacula basimacula: Richards, 1978: 342 (in part; misidentification).

Description. Female: length of fore wing 7.5-10 mm; head nearly as high as wide in frontal view, FHH/INTOW about 1.0; clypeus wider than high, H/WCLP about 0.93 , apex narrowly truncate, clypeus more extensively in contact with eye, free upper part of lateral margin short, hardly more than 0.3 times the clypeus height at middle; malar space narrow; tentorial pit a little closer to eye margin than to antennal socket; occeli as in an equilateral triangle, POL/OOL about $1 / 2$; occiput rounded, carina absent; gena considerably narrower than the upper lobe of the eye; pronotum with lateral fovea, central part of the anterior margin of pronotum with the lamella wide but not reflexed, region immediately behind the lamella produced into a rather incipient secondary margin which is acute but not so strongly projecting over the lamella; humeral angle well developed but not produced into lobe, pronotal carina mostly reduced at center, not lamellate there, nearly straight, not really reflexed at sides, with a very narrow translucent lamellar portion, total width of carina about 1.14 times larger than that of mesoscutum, sides of the pronotum as seen from above not noticeably converging; mesoscutum as long as wide, L/WMS 1.0; fore wing well-elongated, LDIS/HMP 2.4; inner claw of hind tarsus with the apex narrowly pointed, but not acute; propodeum with median furrow long, rather shallow and narrow, developed on 5/6 of the length of propodeal dorsum, propodeal valve narrow, with subtriangular outline; first segment of metasoma only moderately elongated, LSI/HMP about 1.07, about 2.6 times wider at the apex (than at the basal petiole), spiracles not noticeably prominent, petiole cylindrical, not flattened ventrally.

Sculpture: rather indistinct, disk of clypeus dull, mostly with small sized punctures, largerones rare and inconspicuous, area close to the ventral margin finely reticulate with a few isolated large punctures; upper interantennal area and frons similar to clypeus, but with the punctures arranged into a more dense and still duller pattern; mesopleuron with fine punctures, integument never very shining.

Vestiture: eyes bare; hairs beneath gena only moderately long.

Color: yellow; antennal flagellum dark brown dorsally at base to testaceous beneath at the apex; antennal scape and pedicel dorsally, transversal streak on interantennal area (sometimes forming with an upper clypeal line a square shaped mark), bifid frontal mark with wide anterior arms, posteriorly connected to a continuous occipital band which sends a narrow lateral extension to each of the composite eyes, a wide mark on pronotal anterior face, moderately large humeral mark, three wide stripes on mesoscutum coalescing at the extremities, opposite anterior and posterior triangular scutellar marks connected by a median line, moderately wide median stripe and paired anterior triangular and paired posterior oval marks on propodeum, lateral aspect of proepisternum, mesepisternal and scrobal sulci linked to spot on subalar area, small posterior ventral marks on meso and metapleuron, large proximal portions of metasomal terga 1 to 6 , dark brown; two streaks on mid coxa, three streaks on hind coxa, inner aspect of mid and hind trochanters, dorsal elongated marks on femora, linked to a basal ring on mid and hind femora, dorsum of fifth segment of hind tarsus, basal tridentate mark on sternum 2 (rarely), brown or light brown; wing hyaline with brown veins.

Male: length of fore wing $8.0 \mathrm{~mm}$; clypeus touching eyes, a little wider than high, H/WCLP 0.94, ventral angle obtuse, apex narrowly rounded; antenna with the scape relatively shorter and wider, ventral surface of the flagellum with tyloids reduced or fragmented, apex of the antenna very short and broad, antennomere 13 about 1.5 times longer than wide; clypeus without very conspicuous or shining pubescence; frons and gena beneath with more numerous and longer hairs than in female.

Color: similar to female; occipital band with a central discolored window, pronotal marks reduced in size.

Variation: some specimens from Colombia and Panama show the dark marks of a much lighter reddish tonality.

Nest: an examined female specimen (Colombia, Narino, Barbacoas, 7.iv.1974, M. Cooper; NHM/BM1975-33) is referred on the label as from "Nest 67 ", but this nest could not be examined. 

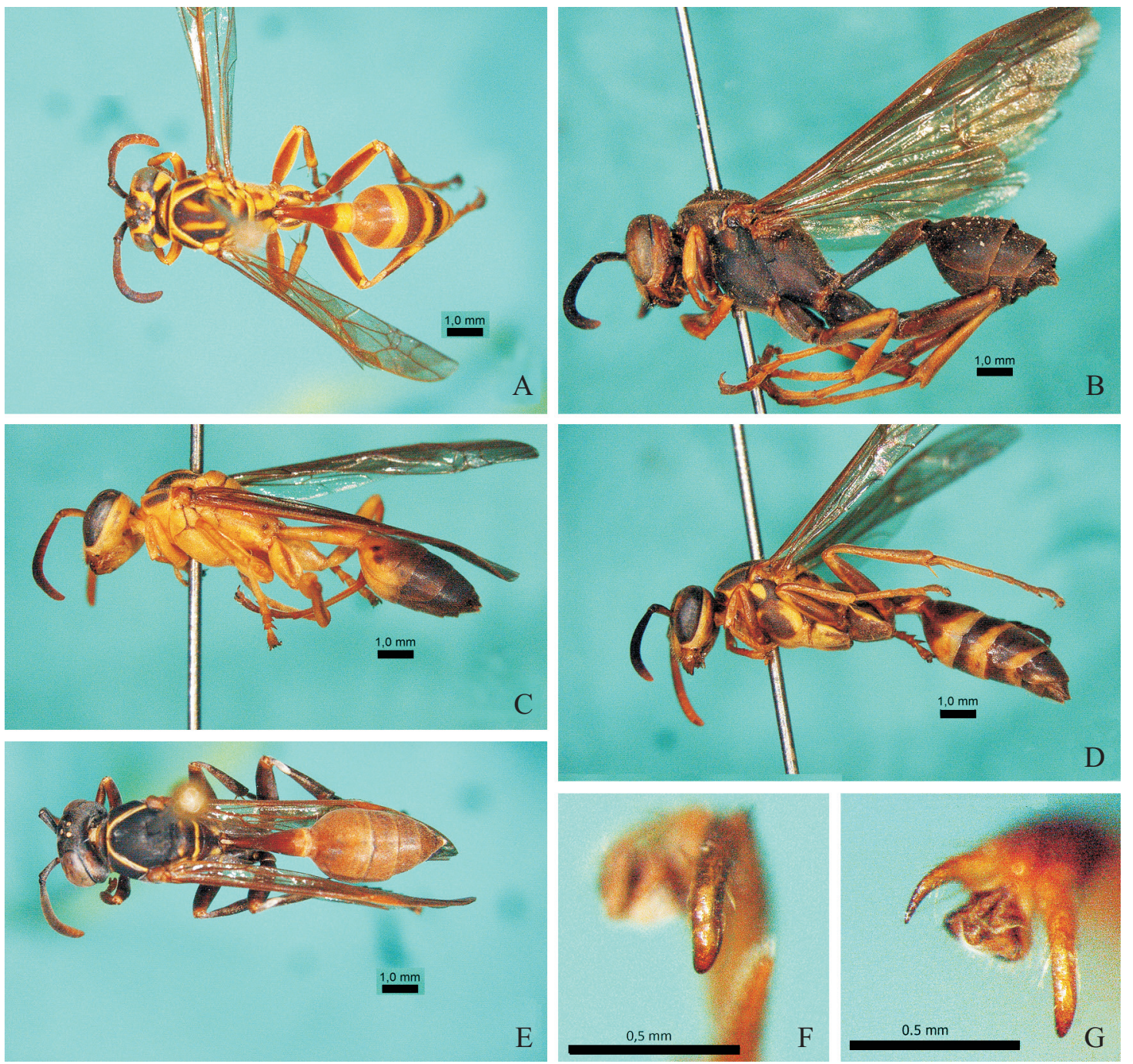

Fig. 5. A-E: general views of M. waunan sp. nov. (A), M. tayacaja sp. nov. (B), M. paraguayensis (C, D), M. suzannae sp. nov. (E); F-G: aspect of the apex of the inner claw of hind tarsus of M. embera sp. nov. (F), and M. awa sp. nov. (G); scale bar measures $1 \mathrm{~mm}$, except in $\mathrm{F}$ and $\mathrm{G}$ where it is $0.5 \mathrm{~mm}$.

Distribution: México: San Luis Potosi, Veracruz, Chiapas; Panama; Colombia: Nariño, Valle.

Etymology: the specific epithet is a reference to the Waunan, an indigenous people that lives in the Pacific Coast of northwestern South America, here used as a noun in apposition.

Remarks. This species was confounded with M. basimacula by Richards (1978: 342). It is indeed similar, but can be distinguished by the less sharp contrast between the yellow and dark colors, and especially by the more homogeneous coloration of the antennal flagellum, by the blackish dorsum of the last segment of the hind tarsus, and the normal absence of a tridentate mark on the base of the second metasomal sternum. Specimens from México were slightly larger on the average, but appeared to be indistinguishable based on morphology and color. The known geographic distribution of $M$. waunan $\mathbf{s p}$. nov. ranges from central México to the Pacific coast of Colombia, but is now notably discontinuous, and the species has not been collected for more than $1500 \mathrm{~km}$ across Central
America, from southern México to northern Panama. Importantly, it has not been found in Costa Rica, which is probably the most intensively collected area in the region.

Type Material. Holotype Female: Colombia, Nariño, Barbacoas, 31.iii.1974, M. Cooper (NHM). Paratypes: México: San Luis Potosi, 10 km SO El Naranjo, 630m, 18.x.1994 (1 female, 2 males), A. Rodriguez; Vera Cruz, Tantoyuca, 27.xii. 1985 (male), F. Noguera, (EBCC); Chiapas, 4 mi SE of Soyalo, 1.iii.1953 (3 females), R. C. Bechtel \& E. J. Schlinger, 18 mi W Tuxtla Guierrez 3000' 25.vii.1952 (Female), Ocozocoautla, 26.vii.1952 (female), E. Gilbert \& C. D. MacNeill (EMEC); $11 \mathrm{~km} \mathrm{~N} \mathrm{Tuxtla}$ Gutierrez, 8.iv. 1993 (female), A. Rodriguez \& F. Noguera, 24 km N Tuxtla Gutierrez, 1165m, nido 32a, 8.iv.1993 (female), A. Rodriguez, Chiapas de Corzo, El Chorreadero, 510m, nido 42a, 23.vii.1997 (5 females), A. Rodriguez (EBCC); Panama: Colón, Est. Biol. Galeta, 30.i.1995 (2 females), E. Pinzón (GBFM); Colombia: Narino, Llorente nr. Tumaco, 25.xi.1977 (2 females, 1 male), M. A. Tidwell (FSCA); Barbacoas, 16-22.xi.1971 (5 females, 3 males), 22.iii.1974 (2 females), 7.iv.1974 (female), 2.vi.1976 (female), M. Cooper (NHM); Barbacoas, 23.iii.1974 (male), M. Cooper (ICN); Valle, Buenaventura, Llano Bajo, 3.x.1971 (female), M. Cooper (NHM); Anchicayá, Hidroeletrica bajo Anchicayá El Engaño 285m, 23.iii.1995 (3 females, nest), C. Sarmiento (ICN). 


\section{Mischocyttarus trinitatis Richards, 1945; n. stat.} (Figs. 3C, 4B)

Mischocyttarus alfkenii var. trinitatis Richards, 1945: 397 (in part); Holotype: Female, Trinidad, Quare Riv. Valley (NHM) [examined]. Mischocyttarus alfkenii trinitatis: Richards, 1978: 344 (in part); O'Connor et al., 2011: 450, 451.

Female: length of fore wing 9-11.5 mm; head nearly as high as wide in frontal view, FHH/INTOW about 1.0; clypeus wider than high, H/WCLP about 0.93 , apex narrowly truncate, clypeus more extensively in contact with eye, free upper part of lateral margin short, hardly more than 0.3 times the clypeus height at middle; malar space narrow; tentorial pit a little closer to eye margin than to antennal socket; occeli as in an equilateral triangle, POL/OOL a little less than $1 / 2$; occiput rounded, carina absent; gena considerably narrower than the upper lobe of the eye; pronotum with lateral fovea, central part of the anterior margin of pronotum with the lamella wide but not reflexed, region immediately behind produced into a secondary margin which is acute and projecting over the lamella; humeral angle well developed and forming weak but distinct lobe, pronotal carina mostly reduced at center, not lamellate there, nearly straight, not reflexed at sides but distinctly prominent laterally, with a distinct rather wide translucent lamellar portion, total width of carina about 1.16 to 1.20 times larger than that of mesoscutum, sides of the pronotum as seen from above not noticeably converging; mesoscutum a little longer than wide, L/WMS about 1.03; fore wing well elongated, LDIS/ HMP around 2.5; inner claw of hind tarsus with the apex narrowly pointed, but not acute; propodeum with median furrow long, rather shallow and narrow, developed on $5 / 6$ of the length of propodeal dorsum, propodeal valve narrow, with subtriangular outline; first segment of metasoma relatively short, LSI/ HMP 1.10, variably wide, from 2.3-2.8 times wider at the apex than at the basal petiole, spiracles not noticeably prominent, petiole cylindrical, not flattened ventrally.

Sculpture: indistinct, disk of clypeus a little shining, mostly with small sized punctures, larger ones rare and inconspicuous, area close to the ventral margin finely reticulate with a few isolated large punctures; mesopleuron with fine indistinct punctures, integument never very shining.

Vestiture: eyes bare; hairs beneath gena only moderately long.

Color: yellow; antennal flagellum light reddish yellow beneath, reddish brown above, scape and pedicel yellow beneath, above diffusely tinged of dark brown; interantennal mark absent; bifid frontal mark with tips of arms narrowed and blurred (sometimes strongly reduced), occipital mark strongly reduced, remaining only a narrow transversal strip and the lateral extensions to eyes and median connection to frontal mark, small central spot on anterior surface of pronotum and humeral mark (often lighter and reduced), three stripes on mesoscutum (often with limits blurred), median line on scutellum, posterior margin of metanotum very narrowly, disc of metasomal terga two to five, dark brown; indistinct marks on mid and hind coxae, elongated marks on dorsal surface of mid and hind femora, sometimes an indistinct interrupted line on propodeal furrow and spots on posterior ventral orifices, central area of first metasomal tergum and base of second, light brown; metasomal terga typically with wide bands; all metasomal sterna yellow; wing hyaline with light yellowish brown veins.

Male: length of fore wing 8-10 mm; clypeus touching eyes, wider than high, H/WCLP 0.90, ventral angle obtuse, apex narrowly rounded; antenna with the scape relatively shorter and wider, ventral surface of the flagellum with tyloids reduced or fragmented, apex of the antenna very short and broad, antennomere 13 about 1.5 times longer than wide; clypeus without very conspicuous or shining pubescence; frons and gena beneath with more numerous and longer hairs than in female.

Color: similar to female, dark marks reduced to a greater extent.

Variation: variation occurs in the degree of reduction of dark marks especially on the occiput, humeral region and terga 1 and 2 of the metasoma. Specimens from the continent tend to be a little darker.

Nest: the nest has been described and figured by Richards (1945) from Venezuela, Caracas, and O'Connor et al. (2011) from Trinidad. Two specimens from Trinidad with very eccentric peduncle were examined (FSCA).

Distribution: Trinidad; Venezuela.

Remarks: This species can easily be distinguished from $M$. alfkenii based on the characters given in the key. Interestingly (because considered by Richards a character of great diagnostic power), the range of variation in the relative length of the first metasomal segment in $M$. trinitatis encompasses most of the summed amplitudes of the alfkenii and paraguayensis groups (see Fig. 2). The type series included specimens of two other species described here with the names $M$. uniformis sp. nov. (from Colombia, Córdoba, Atlántico and Magdalena) and $M$. arawak sp. nov. (from Guyana). Other records by Richards (1978) from Colombia, Putumayo and Valle seem to be mistaken.

Examined Material: Trinidad: Port Spain, 13.ii.1940, H. Caracciola (male, Paratype), Quare Riv. Valley, 25.i.1931, Capt. A. K. totton (female, Paratype) (NHM); Arima valley, $20 . i 1.1985$ (2 females with excentric nest 85-2), Curepe, 19.i.1984 (female with 4-cells nest with dark brown carton), 1.iii.1984 (2 females), 4.iii.1984 (male), 24.iii.1984 (11 males, 15 females), Mayaro, 20.x.1983 (female with excentric nest), 23.x.1984 (female "on nest of P. versicolor"), F. D. Bennett; Chaguaramas, 30.vii.? (female), M. J. Sommerjev; Morne Catharine, 24.iii.1982 (2 females), Santa Cruz La Pastora, 2.vi.1982 (female), M. J. W. Cock (FSCA); Venezuela: Aragua, E Doreste, Cagua, 16.i.1969 (female), 27.x.1969 (female) (without collector), Pto de Cata, 19.ix.1973 (female), B. Villegas (EMEC); Lara, El Cuji, 7.xi.1981 (female), J. M. Osorio (FSCA).

\section{Mischocyttarus baconi Starr, 2011}

Mischocyttarus baconi Starr, 2011: 451 [appendix of O'Connor et al. (2011)]. Holotype: Male, Trinidad, St. Augustine $10^{\circ} 38^{\prime} \mathrm{N}, 61^{\circ} 24^{\prime} \mathrm{W}$, 12.ii.2011, C.K. Starr (AMNH) [not examined].

This species was described from a group of genetically differentiated colonies of a peripheral insular population in 
Trinidad (Starr 2011; in the appendix of O'Connor et al. 2011). The author considered the concept of M. alfkenii sensu Richards (1978) as a reference for comparing the new species, but very probably used only specimens of $M$. alfkenii trinitatis Richards in the genetic assays (as explained earlier, trinitatis is a distinct species). Mischocyttarus baconi actually can only be diagnosed on the basis of DNA characters. Other differences to sympatric colonies of $M$. trinitatis were found by O'Connor et al. (2011) in nest form (peduncle eccentricity and comb shape), and wing morphology (patterns of distances between venational intersections). However, while taking $M$. alfkenii as reference, the authors missed information in Ducke (1905b) demonstrating the existence of large variation in nest form in this species. Regarding wing morphology, the authors could not derive taxonomic diagnostic characters from the (statistical) differences detected by techniques of geometric morphometrics.

Five examined female specimens from a small centric nest (with darker carton) from Trinidad, Tacarigua, 26.iii.1984 (nest 84-27), S. T. Michaels (FSCA) (Fig. 6B) showed considerably broader marginal cell of the fore wing, and are possibly specimens of $M$. baconi. Types of $M$. trinitatis are in fact a mixture of species, and the only nest mentioned and figured by Richards (1945: pl.1, fig. 130) is a small slightly eccentric exemplar from Venezuela, Caracas (USNM). So, while identification of this specimen by Richards is probably correct, little can be said about variation in nest form in the species. Because the holotype of $M$. trinitatis has the marginal cell of the fore wing normally shaped (i.e. not exceedingly broadened), it is probably safe to consider that it represents the form with eccentric nests in the work of O'Connor et al. (2011), otherwise M. baconi should have to be synonymized and a new name created for the form with eccentric nests.

\section{Mischocyttarus arawak sp. nov.}

(Fig. 4C, D)

Mischocyttarus alfkenii var. trinitatis Richards, 1945: 397 (in part; misidentification).

Mischocyttarus alfkenii trinitatis: Richards, 1978: 344 (in part; misidentification).

Description. Female: length of fore wing $9 \mathrm{~mm}$; head nearly as high as wide in frontal view, FHH/INTOW 0.96; clypeus wider than high, H/WCLP 0.92, apex narrowly truncate, clypeus more extensively in contact with eye, free upper part of lateral margin short, 0.31 times the clypeus height at middle; malar space narrow; tentorial pit a little closer to eye margin than to antennal socket; occeli as in an equilateral triangle, POL/OOL a little less than $1 / 2$; occiput rounded, carina $a b-$ sent; gena considerably narrower than the upper lobe of the eye; pronotum with lateral fovea, central part of the anterior margin of pronotum with the lamella wide but not reflexed, region immediately behind produced into a secondary margin which is acute and projecting over the lamella; humeral angle

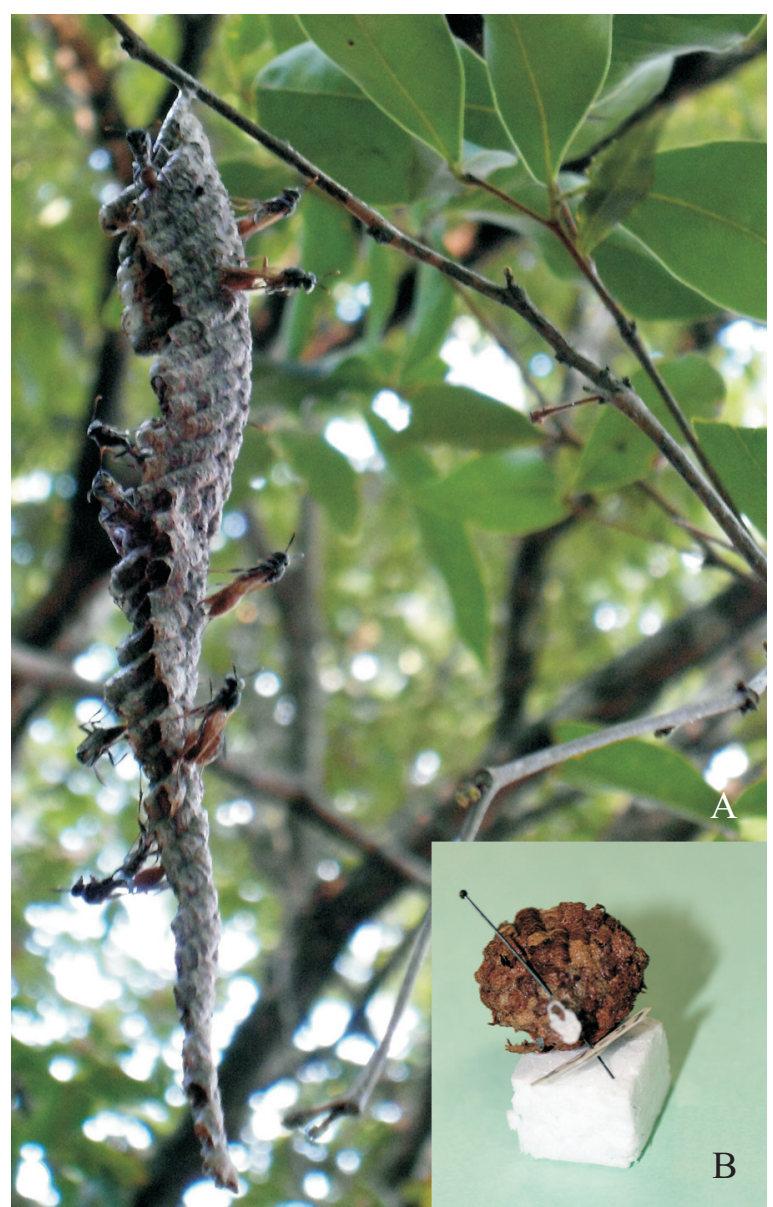

Fig. 6. A: Colony and nest of M. suzannae sp. nov.; B: top view of nest with centric peduncle from Trinidad, referable to M. baconi.

well developed but not produced into lobe, pronotal carina mostly reduced at center, not lamellate there, nearly straight, not reflexed at sides, not very prominent laterally, with a very narrow lamellar portion, total width of carina only 1.12 times larger than that of mesoscutum, sides of the pronotum as seen from above not noticeably converging; mesoscutum a little longer than wide, L/WMS 1.03; fore wing well-elongated, LDIS/HMP 2.4; inner claw of hind tarsus with the apex narrowly pointed, but not acute; propodeum with median furrow long, rather shallow and narrow, developed on 5/6 of the length of propodeal dorsum, propodeal valve narrow, with subtriangular outline; first segment of metasoma moderately elongated, LSI/HMP 1.12, considerably narrow, only 2.10 times wider at the apex than at the basal petiole, spiracles not noticeably prominent, petiole cylindrical, not flattened ventrally.

Sculpture: indistinct, disk of clypeus nearly dull, mostly with small sized punctures, largerones rare and inconspicuous, area close to the ventral margin finely reticulate with a few isolated large punctures; mesopleuron with fine indistinct punctures, integument never very shining.

Vestiture: eyes bare; hairs beneath gena only moderately long.

Color: yellow; antennal flagellum light yellowish brown beneath, dark brown above; scape and pedicel yellow beneath, 
above same color of flagellum; interantennal mark absent; bifid frontal mark with arms well-defined and moderately wide, occipital mark strongly reduced, presenting only a narrow transversal strip and the lateral extensions to eyes and median connection to frontal mark, small poorly defined central spot on anterior surface of pronotum and humeral mark (a little lighter), three stripes on mesoscutum, triangular anterior and posterior areas and median line on scutellum, posterior margin of metanotum narrowly, scrobal furrow and its intersection with mesepisternal sulcus, ventral angle of upper metapleural plate, continuous line on propodeal median furrow, spot on propodeal lateral posterior orifices (continuing anteriorly as a short poorly defined linear mark), all metasomal terga except for narrow distal and lateral marginal areas (progressively narrow backwards, so that sixth tergum is actually unbanded), dark brown; indistinct marks on mid and hind coxae and trochanters, elongated marks on dorsal surface of mid and hind femora and tibiae, fifth segment of hind tarsus, light brown; metasomal terga narrowly banded distally; all metasomal sterna yellow; wing hyaline with brown veins.

Male: unknown

Nest: unknown.

Distribution: Guyana.

Etymology: the specific epithet is a reference to the large Arawak family of languages spoken by once numerous indigenous peoples in South America and West Indies, used here as a noun in apposition.

Remarks: The species is only known from the holotype (previously treated by Richards, 1945 as a paratype of $M$. trinitatis) that is significantly different from $M$. trinitatis in the shape of the pronotal carina, width of the first metasomal tergum, and coloration of the antenna and metasoma (compare figures $4 \mathrm{~B}$ and $\mathrm{D})$.

Type Material: Holotype: Female, Guyana, Mazaruni clearing, 17.ix.1937 (NHM).

\section{Mischocyttarus muisca sp. nov.}

Description. Female: length of fore wing 10-11 mm; head nearly as high as wide in frontal view, FHH/INTOW about 1.0; clypeus wider than high, H/WCLP about 0.90 , apex narrowly truncate, clypeus more extensively in contact with eye, free upper part of lateral margin short, hardly more than 0.3 times the clypeus height at middle; malar space narrow; tentorial pit a little closer to eye margin than to antennal socket; occeli as in an equilateral triangle, POL/OOL a little less than $1 / 2$; occiput rounded, carina absent; gena considerably narrower than the upper lobe of the eye; pronotum with lateral fovea, central part of the anterior margin of pronotum with the lamella wide but not reflexed, region immediately behind produced into a secondary margin which is acute and projecting over the lamella; humeral angle well developed but not produced into lobe, pronotal carina mostly reduced at center, not lamellate there, nearly straight, not really re- flexed at sides, with a narrow but distinct translucent lamellar portion, total width of carina about 1.11 times larger than that of mesoscutum, sides of the pronotum as seen from above not noticeably converging; mesoscutum as long as wide, L/ WMS about 1.0; fore wing normally elongated; inner claw of hind tarsus with the apex narrowly pointed, but not at all acute; propodeum with median furrow long, rather shallow and narrow, developed on 5/6 of the length of propodeal dorsum, propodeal valve narrow, with subtriangular outline; first segment of metasoma moderately elongated, LSI/HMP from 1.07 to 1.15 , about 2.6 times wider at the apex than at the basal petiole, spiracles not noticeably prominent, petiole cylindrical, not flattened ventrally.

Sculpture: indistinct, disk of clypeus dull, mostly with small sized punctures, larger ones rare and inconspicuous, area close to the ventral margin finely reticulate with a few isolated large punctures; mesopleuron with fine indistinct punctures, integument not very shining.

Vestiture: eyes bare; hairs beneath gena only moderately long.

Color: yellow; antennal flagellum reddish brown distally beneath, above dark brown to black, scape and pedicel beneath yellow, above black; bifid frontal mark sometimes with contour disrupted or blurred, occipital mark reduced on its posterior lower parts (sometimes blurred), small indefinite anterior pronotal spot, wide humeral mark, three stripes on mesoscutum, anterior and posterior margins narrowly and median line on scutellum, posterior margin of metanotum narrowly, mesepisternal sulcus narrowly, pleural and propodeal sulci and concavities including a well-defined median line, dark brown or black; one streak on mid coxa, three streaks on hind coxa, elongate marks on dorsal (inner) surface of femora and tibiae, disc of all metasomal terga light reddish brown (testaceous); metasomal terga with narrow yellow distal bands; all metasomal sterna yellow; wing hyaline with brown veins.

Male: length of fore wing $11 \mathrm{~mm}$; clypeus touching eyes, wider than high, H/WCLP 0.88 , ventral angle obtuse, apex narrowly rounded; antenna with the scape relatively shorter and wider, ventral surface of the flagellum with tyloids reduced or fragmented, apex of the antenna very short and broad, antennomere 13 about 1.5 times longer than wide; clypeus without decumbent silvery pubescence, but with well visible short golden hairs ventrally.

Color: similar to female.

Nest: unknown.

Distribution: Colombia: Bolivar, Cundinamarca, and Tolima.

Etymology: the specific epithet is a reference to the Muisca, an indigenous people from the region of Eastern Range of Colombia, used here as a noun in apposition.

Remarks: This species is similar in the testaceous metasoma to $M$. embera $\mathbf{s p . ~ n o v . ~ f r o m ~ P a n a m a , ~ M . ~ u n i f o r m i s ~ s p . ~}$ nov. from northern Colombia, and M. awa sp. nov. from Ecuador. The first and second species can be separated by morphological features (enlarged roundly ending hind tarsal claw and sublobate humeral region of pronotum respectively), 
while $M$. awa sp. nov. can be differentiated from $M$. muisca sp. nov. by the reddish color of marks on head and thorax, and especially the light colored antenna.

Type Material: Holotype: Female, Colombia, Tolima, Melgar, iv.2012, C. Sarmiento (ICN). Paratypes:Colombia: Bolivar, Zambrano, Malaise 2, 9.xii.1993 (male); Cundinamarca, San Antonio, 7.ix.1997 (female), SoraMuñoz; Ubalá, Vereda El Puerto, 20.1 .1998 (female), M. Garcia; Tolima, meseta de Ibagué, 3.v.1999 (female), C. Moreno, J. Gereda (ICN).

\section{Mischocyttarus awa sp. nov.}

(Figs. 4E, 5G)

Description. Female: length of fore wing 10-11 mm; head nearly as high as wide in frontal view, FHH/INTOW about 1.0; clypeus wider than high, H/WCLP about 0.93 , apex narrowly truncate, clypeus more extensively in contact with eye, free upper part of lateral margin short, hardly more than 0.3 times the clypeus height at middle; malar space narrow; tentorial pit a little closer to eye margin than to antennal socket; occeli as in an equilateral triangle, POL/OOL a little less than $1 / 2$; occiput rounded, carina absent; gena considerably narrower than the upper lobe of the eye; pronotum with lateral fovea, central part of the anterior margin of pronotum with the lamella wide but not reflexed, region immediately behind produced into a secondary margin which is acute and projecting over the lamella; humeral angle well developed but not produced into lobe, pronotal carina mostly reduced at center, not lamellate there, nearly straight, not really reflexed at sides, with a narrow but distinct translucent lamellar portion, total width of carina about 1.11 times larger than that of mesoscutum, sides of the pronotum as seen from above not noticeably converging; mesoscutum as long as wide, L/ WMS 1.0; fore wing well-elongated, LDIS/HMP 2.3; inner claw of hind tarsus with the apex narrowly pointed, but not acute; propodeum with median furrow long, rather shallow and narrow, developed on 5/6 of the length of propodeal dorsum, propodeal valve narrow, with subtriangular outline; first segment of metasoma moderately elongated, LSI/HMP 1.12, about 2.6 times wider at the apex than at the basal petiole, spiracles not noticeably prominent, petiole cylindrical, not flattened ventrally.

Sculpture: indistinct, disk of clypeus dull, mostly with small sized punctures, larger ones rare and inconspicuous, area close to the ventral margin finely reticulate with a few isolated large punctures; mesopleuron with fine indistinct punctures, integument never very shining.

Vestiture: eyes bare; hairs beneath gena only moderately long.

Color: yellow; antennal flagellum beneath yellowish brown, above light reddish brown, scape and pedicel beneath yellow, above brown; interantennal mark and bifid frontal mark with contour disrupted or blurred, occipital mark reduced on its lower parts, a small indefinite anterior pronotal spot, wide humeral mark, three stripes on mesoscutum, diffuse mark on scutellum, mesepisternal sulcus narrowly, pleural and propodeal sulci and concavities, reddish brown; one streak on mid coxa, three streaks on hind coxa, elongate marks on dorsal (inner) surface of femora and tibiae, disc of all metasomal terga light reddish brown (testaceous); sometimes metasomal terga with differentiated yellow distal bands; all metasomal sterna yellow; wing hyaline with brown veins.

Male: length of fore wing $10 \mathrm{~mm}$; clypeus touching eyes, wider than high, H/WCLP 0.90, ventral angle obtuse, apex rounded; antenna with the scape relatively shorter and wider, ventral surface of the flagellum with tyloids reduced or fragmented, apex of the antenna very short and broad, antennomere 13 about 1.5 times longer than wide; clypeus without very conspicuous or shining pubescence; frons and gena beneath with more numerous and longer hairs than in female.

Color: similar to female.

Variation: some specimens show the metasomal terga narrowly banded.

Nest: unknown.

Distribution: Ecuador: Manabi, Guayas, El Oro.

Etymology: the specific epithet is a reference to the Awa, an indigenous people that lives in northwestern South America, in Ecuador and Colombia, used here as a noun in apposition.

Remarks: This species may be confounded in terms of its color with either (part of) M. waunan sp. nov., which is smaller with the subalar area marked of black or brown (and with the occipital mark not reduced behind), or with $M$. uniformis sp. nov., which has a higher and prominent (sublobate) pronotal carina at sides (compare Figs. $4 \mathrm{E}$ and F), and a slightly lighter color pattern. Only known from western Ecuador.

Type Material: Holotype: Female, Ecuador, El Oro, 10 km NE Pinas, 7.vii.1989, Stange \& Miller (FSCA). Paratypes:Ecuador: Manabi, Cojimies, vi.1949 (female), W. Clark \& MacIntyre (AEIC); Guayas, 2 mi. S. Manglaralto, 12.vii.1964 (female), D. Q. Cavagnaro; El Oro, 10 km NE Pinas, 7.vii. 1989 (female), 19 km NE Pinas, Hotel Machay, 800m, 1.vii.1989 (female), 2.vii.1989, (2 males), 5.vii.1989 (female) L. Stange \& R. Miller (FSCA).

\section{Mischocyttarus uniformis sp. nov.}

(Fig. 4F)

Mischocyttarus alfkenii var trinitatis Richards, 1945: 397 (in part; misidentification).

Description. Female: length of fore wing 9-11.5 mm; head nearly as high as wide in frontal view, FHH/INTOW about 1.01; clypeus wider than high, H/WCLP about 0.93 , apex narrowly truncate, clypeus more extensively in contact with eye, free upper part of lateral margin short, hardly more than 0.3 times the clypeus height at middle; malar space narrow; tentorial pit a little closer to eye margin than to antennal socket; occeli as in an equilateral triangle, POL/OOL a little less than $1 / 2$; occiput rounded, carina absent; gena considerably narrower than the upper lobe of the eye; pronotum with lateral fovea, central part of the anterior margin of pronotum with the lamella wide but not reflexed, region immediately behind produced into a secondary margin which is acute and 
projecting over the lamella; humeral angle well developed and forming weak but distinct lobe, pronotal carina mostly reduced at center, not lamellate there, nearly straight, not reflexed at sides but distinctly prominent laterally, with a distinct rather wide translucent lamellar portion, total width of carina about 1.15 times larger than that of mesoscutum, sides of the pronotum as seen from above not noticeably converging; mesoscutum as long as wide, L/WMS 1.0; fore wing well-elongated, LDIS/HMP 2.4; inner claw of hind tarsus with the apex narrowly pointed, but not acute; propodeum with median furrow long, rather shallow and narrow, developed on $5 / 6$ of the length of propodeal dorsum, propodeal valve narrow, with subtriangular outline; first segment of metasoma relatively short, LSI/HMP 1.07, variably wide, from 2.5-2.8 times wider at the apex than at the basal petiole, spiracles not noticeably prominent, petiole cylindrical, not flattened ventrally.

Sculpture: indistinct, disk of clypeus a little shining, mostly with small sized punctures, larger ones rare and inconspicuous, area close to the ventral margin finely reticulate with a few isolated large punctures; mesopleuron with fine indistinct punctures, integument never very shining.

Vestiture: eyes bare; hairs beneath gena only moderately long.

Color: yellow; antennal flagellum uniformly light reddish brown, scape and pedicel beneath yellow, above same color of flagellum; interantennal mark reduced and bifid frontal mark with contour blurred or very narrow, occipital mark strongly reduced on its lower parts, three stripes on mesoscutum, reddish brown; one streak on mid coxa, two streaks on hind coxa, elongate marks on dorsal surface of mid and hind femora and tibiae, disc of all metasomal terga, light to darker testaceous brown; metasomal terga with variably differentiated yellow distal bands; all metasomal sterna yellow; wing hyaline with brown veins.

Male: unknown.

Variation: some specimens show the metasomal terga narrowly banded.

Nest: described by O. W. Richards (unpublished manuscript) as having "a broad peduncle, $4.0 \mathrm{~mm}$ long, $3.0 \mathrm{~mm}$ wide, light brownish grey in colour... comb long ovals $(4.0 \mathrm{x}$ $2.5 \mathrm{~cm}) \ldots$ peduncle near the middle of the comb ... completed cells 11.0 x $3.5 \mathrm{~mm}$ ".

Distribution: Colombia: Atlántico, Córdoba, Magdalena.

Etymology: the specific epithet refers to the rather uniform pale coloration.

Remarks: This species was confounded with $M$. trinitatis by O. W. Richards in the revision of Mischocyttarus of 1945, but was subsequently recognized by him as a distinct species in an unpublished manuscript.

Type Material: Holotype: Female, Colombia, Magdalena, N. Sierra Nevada de Santa Marta, Rio Buritaca 100m, 8.iii.1974, M. Cooper (NHM). Paratypes:Colombia: Atlantico, Puerto Colombia, C. Morley (female, Paratype of M. trinitatis; NHM); Córdoba, San Antero, Amaya 0m, 14.i.1999 (female), D. Campos; Magdalena, PNN Tayrona (female) (ICN); N. Sierra Nevada de Santa Marta, Rio Buritaca 100m, 8.iii.1974, (3 females) Nest 7, M. Cooper (NHM).
Mischocyttarus achagua sp. nov.

(Fig. 3E)

Description. Female: length of fore wing $10.5 \mathrm{~mm}$; head nearly as high as wide in frontal view, FHH/INTOW 0.98; clypeus wider than high, H/WCLP 0.92, apex narrowly truncate, clypeus more extensively in contact with eye, free upper part of lateral margin short, hardly more than 0.3 times the clypeus height at middle; malar space narrow; tentorial pit a little closer to eye margin than to antennal socket; occeli as in an equilateral triangle, POL/OOL about 1/2; occiput rounded, carina absent; gena considerably narrower than the upper lobe of the eye; pronotum with lateral fovea, central part of the anterior margin of pronotum with the lamella wide but not reflexed, region immediately behind produced into a secondary margin which is acute and projecting over the lamella; humeral angle well developed but not produced into lobe, pronotal carina mostly reduced at center, not lamellate there, nearly straight, not really reflexed at sides, with a narrow but definite translucent lamellar portion, total width of carina about 1.13 times larger than that of mesoscutum, sides of the pronotum as seen from above not noticeably converging; mesoscutum just a fraction longer than wide, L/WMS 1.03; fore wing moderately elongated, LDIS/HMP 2.25; inner claw of hind tarsus rather broad with the apex round; propodeum with median furrow long, rather shallow and narrow, developed on 5/6 of the length of propodeal dorsum, propodeal valve relatively wide, with subtriangular outline; first segment of metasoma well elongated, LSI/HMP 1.16, about 2.54 times wider at the apex than at the basal petiole, spiracles not noticeably prominent, petiole cylindrical, not flattened ventrally.

Sculpture: rather indistinct, disk of clypeus dull, mostly with small sized punctures, larger ones rare and inconspicuous, area close to the ventral margin finely reticulate with a few isolated large punctures; mesopleuron with small punctures with perceptible interstices, not very shining.

Vestiture: eyes bare; hairs beneath gena only moderately long.

Color: yellow; antennal flagellum beneath light reddish brown, dark brown above; antennal scape and pedicel beneath yellow, dark brown above; bifid frontal mark with broad anterior arms, posteriorly connected to an occipital band which sends two narrow extensions to composite eyes and is reduced on its lower parts, a wide mark on pronotal anterior face, large humeral mark, three stripes on mesoscutum coalescing at the extremities, dark brown; median line and anterior and posterior margins of scutellum narrowly, posterior margin of metanotum narrowly, median stripe and paired anterior triangular and paired posterior oval marks on propodeum, mesepisternal and scrobal sulci linked to spot on subalar area, ventral angle of upper metapleural plate, small diffuse posterior ventral marks on meso and metapleuron, two streaks on mid coxa, three streaks on hind coxa, dorsal aspect of mid and hind femora, tibiae and tarsi, light brown, distal tarsomeres darker; metasomal terga light brown with narrow yellow distal bands; all metasomal sterna yellow; wing hyaline with brown veins. 
Male: unknown.

Nest: unknown.

Distribution: Colombia, Meta.

Etymology: the specific epithet is a reference to the Achagua, an indigenous people that lives in northwestern South America, in Colombia, used here as a noun in apposition.

Remarks: This species and the next share as distinctive feature a large and broadly pointed hind tarsal claw (see Fig. $5 \mathrm{~F}$ ), an unusual character in both groups of alfkenii and paraguayensis. The structure of the head in respect to the shape of the clypeus and relations with other head elements indicate these species pertain to the alfkenii group. However, the relatively long first metasomal segment of M. achagua is unique in this group.

Type Material: Holotype: Female, Colombia, Meta, El Porvenir, 27.ii.1979 (female), R. Wilkerson (FSCA). Paratype:Colombia: Meta, Puerto Gaitán, Fundación Yamato, iv.1997 (female) (ICN).

\section{Mischocyttarus embera sp. nov.}

(Figs. 3F; 5F)

Description. Female: length of fore wing $10 \mathrm{~mm}$; head nearly as high as wide in frontal view, FHH/INTOW 1.0; clypeus much wider than high, H/WCLP 0.88 , apex narrowly truncate, clypeus more extensively in contact with eye, free upper part of lateral margin short, hardly more than 0.3 times the clypeus height at middle; malar space very narrow; tentorial pit distinctly closer to eye margin than to antennal socket; occeli as in an equilateral triangle, POL/OOL about 1/2; occiput rounded, carina absent; gena considerably narrower than the upper lobe of the eye; pronotum with lateral fovea, central part of the anterior margin of pronotum with the lamella wide but not reflexed, region immediately behind produced into a secondary margin which is acute and projecting over the lamella; humeral angle well developed but not produced into lobe, pronotal carina mostly reduced at center, not lamellate there, nearly straight, not really reflexed at sides, with a narrow but definite translucent lamellar portion, total width of carina about 1.13 times larger than that of mesoscutum, sides of the pronotum as seen from above not noticeably converging; mesoscutum just a fraction longer than wide, L/WMS 1.03; fore wing moderately elongated, LDIS/HMP 2.26; inner claw of hind tarsus broad with the apex round; propodeum with median furrow long, rather shallow and narrow, developed on $5 / 6$ of the length of propodeal dorsum, propodeal valve relatively wide, with subtriangular outline; first segment of metasoma short, LSI/HMP 1.08, about 2.43 times wider at the apex than at the basal petiole, spiracles not noticeably prominent, petiole cylindrical, not flattened ventrally.

Sculpture: rather indistinct, disk of clypeus a little shining, mostly with small sized punctures, larger ones rare and inconspicuous, area close to the ventral margin finely reticulate with a few isolated large punctures; mesopleuron with small but clearly perceptible punctures, interstices a little shining.
Vestiture: eyes bare; hairs beneath gena only moderately long.

Color: yellow; antennal flagellum beneath light reddish brown, dark brown above; antennal scape and pedicel beneath yellow, above dark brown; frontal mark with contour blurred, posteriorly connected to a narrow occipital band which sends two extensions to the composite eyes and is reduced on its lower parts, a very small indistinct mark on pronotal anterior face, large humeral mark, three stripes on mesoscutum coalescing at the extremities, median line and anterior triangular mark on scutellum, posterior margin of scuttelum and metanotum narrowly, median stripe and paired posterior orifices on propodeum, reddish brown or a little darker, blackish; small diffuse posterior ventral marks on lower metapleuron, diffuse triangular spots on propodeum anteriorly, two streaks on mid coxa, three streaks on hind coxa, dorsal aspect of mid and hind femora and tibiae, metasomal terga, light testaceuous brown; metasomal terga unbanded; all metasomal sterna yellow; wing hyaline with brown veins.

Male: unknown.

Nest: unknown.

Distribution: Panama.

Etymology: the specific epithet refers to Embera as a group of languages spoken by indigenous peoples living in Colombia and Panama, used here as a noun in apposition. In particular, the word means "human being".

Remarks: This species can be easily separated from $M$. achagua sp. nov. by its much shorter first metasomal segment, and completely testaceous metasoma. From $M$. uniformis sp. nov., M. muisca sp. nov., and M. awa sp. nov. it can be distinguished by the enlarged broadly pointed hind tarsal claw (see Fig. 5F).

Type Material: Holotype: Female, Panama, P. N. Metropol., Mini-Malaise ANAE 8, 17-24.v.1994 (female), V. Rodriguez (GBFM)

\section{Group of M. paraguayensis and bahiae}

Refers to a group of six known species with the characters given in couplet 1 ' of the key.

\section{Mischocyttarus paraguayensis Zikán, 1935}

(Figs. 3A; 5C, D)

Mischocyttarus paraguayensis Zikán, 1935: 165, figs. 23, 25, 28, 30; Lectotype: Male, Paraguay, Mbovevo (MZSP) [examined].

Mischocyttarus paraguayensis: Zikán, 1949: 163, figs. 101, 102, 243, 244, 378; Richards, 1945: 379, 380, 400, fig. 55 (misidentification); 1978 : 339; Willink, 1953: 238, figs. 18-20; Silveira, 2008: 540.

Mischocyttarus similatus Zikán, 1935: 187, figs. 51, 53, pl. 3 - fig. 7. Holotype Female, Brazil, Itatiaia (IOC) [examined]; Zikán, 1949: 138; Richards, 1978: 357. N. syn.

Mischocyttarus itatiayaensis Zikán, 1935: 190, figs. 58, 61, 62. Lectotype Female, Brazil, Itatiaia (IOC), designated by Richards (1978) [examined]; Zikán, 1949: 179, figs. 115,116, 263, 264, 389; Richards, 1978: 353. N. syn.

Mischocyttarus alfkenii var. zikanii Richards, 1945: 399; synonymy by Richards (1978: 339). Holotype Female, Paraguay, Pto. Bertoni (NHM) [examined] 
Mischocyttarus schrottkyi Zikán, 1949: 159. Holotype Female, Paraguay, Puerto Bertoni (MZSP; n. 16.438) [examined]. N. syn.

Mischocyttarus gilvus Zikán, 1949: 159. Holotype Male, Paraguay, Puerto Bertoni (MZSP) [examined]; Richards, 1978: 346. N. syn.

Mischocyttarus aracatubaensis Zikán, 1949: 162, fig. 412. Holotype Female, Brazil, São Paulo (IOC) [examined]; Richards, 1978: 345. N. syn.

Mischocyttarus similaris Zikán, 1949: 167, fig. 248. Holotype Female, Brazil, São Paulo, Ilha Seca (IOC) [examined]; Richards, 1978: 360. N. syn.

Mischocyttarus araujoi Zikán, 1949: 173, figs. 255, 256, 391. Lectotype Male, Brazil, São Paulo, Amparo (IOC), designated by Richards (1978) [examined]; Richards, 1978: 355. N. syn.

Mischocyttarus infrastrigatus Zikán, 1949: 175, figs. 112, 257, 390. Lectotype Male, Brazil, Itatiaia (IOC), designated by Richards (1978) [examined]; Richards, 1978: 360. N. syn.

Mischocyttarus infrastrigatoides Zikán, 1949: 236. Lectotype Female, Brazil, Itatiaia (IOC), designated by Richards (1978) [examined]; Richards, 1978: 360 (as synonym of infrastrigatus). N. syn.

Mischocyttarus scitulus Zikán, 1949: 176, figs. 113, 258, 259. Lectotype Male, Brazil, Itatiaia (IOC), designated by Richards (1978) [examined]; Richards, 1978: 359. N. syn.

Mischocyttarus ornatulus Zikán, 1949: 177, figs. 114, 260, 261, 392. Lectotype Male, Brazil, Itatiaia (IOC), designated by Richards (1978) [examined]; Richards, 1978: 360 (as synonym of infrastrigatus). N. syn.

Mischocyttarus mutator Zikán, 1949: 178, fig. 262. Lectotype Female, Brazil, Itatiaia (IOC), designated by Richards (1978) [examined]; Richards, 1978: 361. N. syn.

Mischocyttarus costalimai Zikán, 1949: 180, figs. 117, 118, 265, 266, 401. Lectotype Male, Brazil, Itatiaia (IOC), designated by Richards (1978) [examined]; Richards, 1978: 354. N. syn.

Mischocyttarus rivulorum Richards, 1978: 354. Holotype Female, Argentina, Entre Rios, Rio Uruguai, Isla Pepe-Aji (IMLA), Paratype Female, same data (NHM) [examined]. N. syn.

Mischocyttarus riograndensis Richards, 1978: 363. Holotype Female, Brazil, Rio Grande doDescription: Sul, São Leopoldo (MZSP) [examined]. N. syn.

Female: length of fore wing $8.5-10.5 \mathrm{~mm}$; head nearly as high as wide in frontal view, FHH/INTOW more often less than 1.0; clypeus considerably wider than high, mean $\mathrm{H} /$ WCLP 0.88 (upper limit: 0.93), apex narrowly truncate, clypeus less extensively in contact with eye, free upper part of lateral margin longer, more than 0.33 times clypeus height at middle; malar space narrow; tentorial pit a little closer to eye margin than to antennal socket; occeli as in an equilateral triangle, $\mathrm{POL} / \mathrm{OOL}$ about $1 / 2$; occiput rounded, carina absent; gena considerably narrower than the upper lobe of the eye; pronotum with lateral fovea, central part of the anterior margin of pronotum with the lamella wide but not reflexed, region immediately behind produced into a secondary margin projecting over the lamella; humeral angle well developed but not produced into lobe, pronotal carina mostly reduced at center, not lamellate there, not really reflexed and little prominent at sides, with very narrow lamellar portion, total width of carina about 1.07-1.13 times larger than that of mesoscutum, sides of the pronotum as seen from above not noticeably converging forwards; mesoscutum about as long as wide, L/WMS about 1.0; fore wing well-elongate, LDIS/HMP 2.4-2.6, inner claw of hind tarsus with the apex pointed but not acute; propodeum with median furrow long, moderately deep and wide, developed on $4 / 5$ of the length of propodeal dorsum, propodeal valve relatively wide, with a subtriangular outline; first segment of metasoma well elon- gated, mean LSI/HMP 1.12 , more than 1.1 in $84 \%$ of the instances (see Fig. 2), moderately wide, about 2.4 times wider at the apex than at the basal petiole, spiracles not noticeably prominent, petiole cylindrical, not flattened ventrally.

Sculpture: moderately distinct, considerably stronger than in M. alfkenii, the small punctures deeper and more conspicuous; clypeus mostly with small sized punctures, larger ones more scattered and inconspicuous, area close to the ventral margin finely reticulate and a little shining, with a few isolated large punctures; mesopleuron with small punctures, with granulate appearance, integument little shining.

Vestiture: eyes bare; hairs beneath gena only moderately long.

Color: extremely variable, from almost completely black insects, passing by variegated patterns of black with yellow marks, to mostly yellow with black or brown marks, sometimes the whole range (or nearly) of color patterns found within a single nest. Remarkable cases of extreme within-nest variation are the type series of $M$. araujoi Zikán, and some large colonies of M. gilvus Zikán (Argentina, C. \& M. Vardy coll., 8.iv.1974, nest 15, NHM; Paraguay, P. N. Ybicuí, 27.ii.1995, B. Garcete Barrett, INBP). The latter name was originally associated to a color pattern resembling the epiponine species Agelaia pallipes, a yellow insect with the metasoma distally painted of black, which is imitated by a number of other wasp species (including various Mischocyttarus in different subgenera, as M. montei Zikán, M. cerberus Ducke, M. tricolor Richards, and M. collarellus Richards). While not recognizing M. gilvus in material from Paraguay, Garcete-Barrett (1999) commented on the possibility that it could be in fact not more than a color variant of M. paraguayensis.

Male: length of fore wing $9.5 \mathrm{~mm}$; clypeus narrowly separated from eyes, wider than high, H/WCLP about 0.88 , ventral angle obtuse, apex narrowly rounded; antenna with the scape relatively shorter and wider, ventral surface of the flagellum with tyloids reduced or fragmented, apex of the antenna short and broad, antennomere 13 about 2.5 times longer than wide; clypeus without very conspicuous or shining pubescence; hairs on frons and gena beneath not very different of the condition in female.

Nest: published reports and figures indicate architecture composed of an oval more or less elongate comb and eccentric peduncle (Richards 1978; Zikán 1935, 1949). Zikán (1949) presented several photographs of nests under the names M. paraguayensis (Fig. 378), M. infrastrigatus (Fig. 389), M. infrastrigatus (Fig. 390), M. araujoi (Fig. 391), M. ornatulus (Fig. 392), M. costalimai (Fig. 401), and M. aracatubaensis (Fig. 412). Particularly the nests in Zikán's figures 392 and 401 have very long combs up to five times longer than wide.

Distribution: Brazil: Mato Grosso do Sul, Minas Gerais, Rio de Janeiro, São Paulo, Paraná, Santa Catarina, Rio Grande do Sul; Paraguay; Argentina: Buenos Aires, Entre Rios, Misiones.

Remarks: The revised concept of $M$. paraguayensis presented here resulted from at least three years of careful observations of large numbers of specimens, and included two visits to the Instituto Oswaldo Cruz to study the Zikán Col- 
lection. Detailed analyses of published identification keys and of qualitative and morphometric data of specimens referable to the "M. alkenii and consimilis" group of Richards (1978) has failed to recover taxonomic structure in any way resembling the very diversified arrangements of species found in that work or in Zikán (1949). Characters often referred to in keys, such as "length of malar space", "asymmetry of tarsal segments", "shape of propodeal furrow", and "length of first metasomal segment" simply do not vary in ways that could provide diagnostic characters at so fine a level (and so recurrently used) as one can see in the published keys. The numerous species described by Zikán from Itatiaia cannot be separated even by color differences. Furthermore, extreme color variants may exist in a single nest as in the type series of $M$. araujoi Zikán, or in some large nests of M. gilvus Zikán.

Examined Material: Brazil: Mato Grosso do Sul, Mundo Novo, 17.i.2011 (2 females, 2 males), Torres V. O. (MPEG); Minas Gerais, Barroso, 08.xii.2003 (3 females), 10.i.2004 (3 females), 30.x.2004 (3 females), Souza M. M., Nascimento M. A., Silva M. \& Silva M. A.; São Gonçalo do Sapucaí, 16.v.2012 (2 females, 2 males), Souza, M. M. (MPEG); Rio de Janeiro, Itatiaia, 900m, Itaoca, 5.xi.1931 (female Paralectoype of itatiayaensis), 816m, Bau 68, 13.xii.1935-1.i.1936 (6 females, 2 males), 700m, Bau 70, 20.xii.1935 (female), 700m, Bau 79, 22.iii.1936 (female, male), Bau 15, 25.x.1941 (female), Bau 6, 8.xi.1941 (female), 700m, Bau 43, 20.ii.1941 ( 2 females, 2 males Paralectotypes of ornatulus), Bau 113, 11.ii.1941 (female), 700m, Bau 94, 15.vii.1941 (female Paralectotype of scitulus), Bau 164, 14.ii.1942 (male), 23.ii.1942 (2 females), 10.ii.1944 (male), Km 2, 7.i.1941 (2 females), Bau 154, 11.ii.1942 (female, male Paralectotypes of infrastrigatus), 24.ii.1942 (female), Bau 175, $23 . i 1.1942$ (female, male Paralectotypes of costalimai), Bau 2, Faz. Valparaiso, 9.iii.1942 (2 females), Bau 3, Faz. Valparaiso, 9.iii.1942 (female), 12.iii.1942 (female), J. F. Zikán (IOC); Rio Grande do Sul, Estrela Velha, 10.i.2011 (female), A. Somavilla coll., Santa Cruz do Sul, 08.ii.2003 (2 females), Vera Cruz (female, male) 14.i.2003, M. G. Hermes (MPEG); São Leopoldo?, no. 1210 (male Paratype of $M$. riograndensis) (MZSP); Santa Catarina, Nova Teutônia, (female) F. Plaumann (IOC); São Paulo, Araras, 22.iv.1984 (7 females, 1 male), F. D. Bennett (FSCA), Amparo, Brumado, 25.v.1944 (3 females Paralectotypes of araujoi) (IOC), Rio Claro, Ajapi, 19.v.1968 (9 females) (NHM), São Carlos, 6.ii.1971 (female), O. W. Richards (NHM), São Carlos (female), del Lama coll. (MPEG); Paraguay: Canindeyú, Rio Carapá 9 km S de Katueté, 17.ii.1984 (male), Bonace coll.; Res. Nat. Bos. Mbaracayú, Lagunita, 10.ix.1995 (male); Cordillera, Caacupé, Camp. J. Norment, 27.i.1995 (3 females) B. Garcete Barrett (INBP); Guairá, Mbovevo, 25.iii.1933 (female, 2 males Paralectotypes of paraguayensis), Schade (IOC); Paraguari, Ybicuí, 24.i.1982 (2 females) H. Ferreira coll.; P. N. Ybicuí, 17.i.1995 (nest 226; 5 females), 19.i.1995 (nest 229b; 4 females), 18.ii.1995 (nest 242; 27 females, 45 males), 27.ii.1995 (11 females, 23 males), B. Garcete Barrett (INBP); Argentina: Buenos Aires, Punta Lara, 26.i.1966 (female), 27.i.1966 (female), 31.i.1966 (female), H. \& M. Townes (AEIC); Entre Rios, 10.v.1963 (female Paratype of M. rivulorum), Misiones, Puerto Iguazu, 8.iv.1974 (21 females, 12 males), C. \& M. Vardy (NHM).

\section{Mischocyttarus catharinaensis Zikán, 1949}

Mischocyttarus catharinaensis Zikán, 1949: 175, fig. 348; Holotype: Female, Brasil, Santa Catarina, Nova Teutônia (IOC) [examined]. Richards, 1978: 358 .

Female: length of fore wing $10.5 \mathrm{~mm}$; morphology generally as in the preceding species, but with pronotal carina exceptionally high and prominent at sides for this group, and first metasomal segment relatively slender and with prominent spi- racles (see also Richards, 1978); clypeus wider than high, H/ WCLP 0.91, less extensively in contact with eye, free upper part of lateral margin longer, more than 0.33 times clypeus height at middle; pronotal carina mostly reduced at center, not lamellate there, considerably high and prominent at sides, with a distint lamellar portion; fore wing well-elongate, LDIS/HMP 2.4; first segment of metasoma very elongated, LSI/HMP 1.22, and relatively narrow, 2.31 times wider at the apex than at the basal petiole, spiracles considerably prominent.

Color has been described by Zikán (1949) and Richards (1978) and is generally alike the darker patterns observed in M. paraguayensis.

Male: unknown.

Nest: unknown.

Distribution: Brazil: Santa Catarina.

Remarks: The species is only known from the holotype. Except for the diagnostic features, it is quite similar to dark forms of $M$. paraguayensis. New material from the relevant localities would be necessary to develop a more well-founded appreciation of the status of $M$. catharinaensis.

\section{Mischocyttarus bahiae Richards, 1945}

Mischocyttarus alfkenii var. bahiae Richards, 1945: 398 (in part); Holotype: Female, Brazil (NHM) [examined].

Mischocyttarus bahiae: Zikán, 1949: 161, figs. 99, 100, 242, 400; Richards, 1978: 345.

Mischocyttarus fluminensis Zikán, 1949: 169, figs. 251, 388; Richards, 1978 : 356. Lectotype: Female, Brazil, Rio de Janeiro (IOC) [examined]. N. syn.

Female: length of fore wing 9-11.5 mm; head nearly as high as wide in frontal view, FHH/INTOW about 1.0; clypeus considerably wider than high, H/WCLP 0.90 , apex narrowly truncate, clypeus less extensively in contact with eye, free upper part of lateral margin longer, more than 0.33 times clypeus height at middle; humeral angle well developed but not produced into lobe, pronotal carina mostly reduced at center, not lamellate there, nearly straight, not really reflexed and little prominent at sides, with a very narrow lamellar portion, total width of carina about 1.07-1.12 times larger than that of mesoscutum, sides of the pronotum as seen from above not noticeably converging forwards; mesoscutum about as long as wide, L/WMS about 1.0; fore wing well elongate, LDIS/HMP 2.3-2.43, inner claw of hind tarsus with the apex pointed but not acute; propodeum with median furrow long, moderately deep and wide, developed on 4/5 of the length of propodeal dorsum, propodeal valve relatively wide, with a subtriangular outline; first segment of metasoma well elongated, LSI/HMP about 1.12 , moderately wide, about 2.4 times wider at the apex than at the basal petiole, spiracles not noticeably prominent.

Sculpture: generally like in $M$. paraguayensis, not so distinct but a little stronger than in $M$. alfkenii, the small punctures a little deeper and conspicuous; clypeus mostly with small sized punctures, larger ones more scattered and inconspicuous, area close to the ventral margin finely reticulate and a little shining, with a few isolated large punctures; mesopleuron with small punctures, integument little shining. 
Vestiture: eyes bare; hairs beneath gena only moderately long.

Color: yellow; antennal pedicel and flagellum above reddish brown to black, light reddish brown beneath (lighter to the apex), scape light brown to black above, yellow beneath (including base of pedicel); sometimes dorsal margin of clypeus (narrowly) and an inverted T-shaped mark on interantennal area (sometimes a large quadrate supraclypeal mark); bifid frontal mark with very wide anterior arms sometimes extending laterally into ocular sinus and centrally enclosing a trilobate yellow mark, very broad around ocelli and posteriorly connected to a narrow (looking blurred) occipital band which sends two lateral extensions to the composite eyes, a variably wide dark mark on pronotal anterior face, large (more often) humeral mark, most of mesoscutum letting two narrow yellow stripes centrally, and variably narrow marginal pale areas adjacent to tegulae, opposite triangular (often) anterior and posterior scutellar marks connected by a median line, sometimes mark on posterior third of metanotum with the anterior border angled medially, mesepisternal and scrobal sulci very narrowly, rarely a small ventral spot on mesepisternum, ventral angle of upper metapleura, median stripe on propodeal furrow and spots on posterior orifices, dark brown with a reddish tinge on the borders of marks; sometimes a diffuse transversal mark on scutellum, rather large anterior triangular areas on propodeum (sometimes absent and the propodeum almost completely yellow), connecting behind with spots on the posterior orifices and anteriorly with diffuse posterior mark on lower metapleura, two stripes on mid coxa, three on hind coxa, elongated marks on mid and hind femora and tibiae, mid and hind tarsi (distal segments darker), light brown; all metasomal terga and sterna, testaceous brown, without evident banded patterns (rarely tergum 1 with yellow distal band, tergum 2 basally tinged of yellow, sternum 2 yellow, and remaining segments 3 to 6 black or blackish); wing hyaline with yellow brown veins.

Male: length of fore wing $9.5 \mathrm{~mm}$; clypeus narrowly separated from eyes, a little wider than high, H/WCLP 0.92, ventral angle obtuse, apex rounded; antenna with the scape relatively shorter and wider, ventral surface of the flagellum with tyloids reduced or fragmented, apex of the antenna short and broad, antennomere 13 about 2.5 times longer than wide; clypeus without very conspicuous or shining pubescence; hairs on frons and gena beneath not very different of the condition in female.

Nest: Zikán (1949) presented photographs of two nests, one under the name M. fluminensis (Fig. 388) being a small nest with some fifteen to twenty cells and an eccentric peduncle; the second nest under the name $M$. bahiae was larger, with about 45 cells and the comb with a more circular contour (Fig. 400).

Distribution: Brazil: Ceará, Pernambuco, Bahia, Rio de Janeiro, Minas Gerais.

Remarks: Mischocyttarus fluminensis Zikán seems to be just a darker form of $M$. bahiae Richards (several instances of transition having been observed), both differing from $M$. paraguayensis by the completely testaceous metasoma, practically without banded patterns, and the mostly yellow mesopleuron and propodeum. Two paratypes of $M$. bahiae from the state of Pernambuco (NHM) have the more distal segments of the metasoma black, in a pattern similar to that observed in the southern form M. gilvus Zikán, which is synonymyzed here to $M$. paraguayensis. However, while extreme color variants have been observed in single nests of $M$. paraguayensis, a relatively large colony (Bau 54, 15 females, 1 male) of $M$. bahiae observed in the IOC collection only comprised individuals of the typical testaceous pattern.

Examined Material: Brazil: Ceará, Serra de Baturité 700m, 18.vii.1908 (3 females), A. Ducke (MPEG); "Brazil, F. Smith coll. pres. by Mrs. Farren White" (female; Paratype of bahiae Richards) (99-303-NHM), Bahia, 26.x.23 (male; Paratype of bahiae Richards), W. S. Bristowe (30.467 NHM), Bahia (male; Paratype of bahiae Richards), Gomez (ZMB); Bahia, i.1935, Bau 54 (15 females, 1 male), Froes, Bonfim, ix.1937 (female) coll. J.P.F. (IOC); Rio de Janeiro, Rio de Janeiro (female; Paralectotype of fluminensis Zikán),Hugo Souza Lopes (IOC); (Itatitaia ?), Km 47, Lote1, xi.1970 (3 females), W. Zikán (MZSP); Minas Gerais, Belo Horizonte, 22.iv.2000 (female), Zanette, L. R. S. (MPEG), Parque Rio Doce (municipalities of Marliéria, Timóteo e Dionísio), 13.i.2010 (female), Souza M., Ladeira T., Ferreira M. \& Pires E. (MPEG).

\section{Mischocyttarus flavoniger Zikán, 1949}

Mischocyttarus flavoniger Zikán, 1949: 170; Lectotype: Female, Peru, Valle Chanchamayo 800m, Weyrauch (IOC); designated by Richards (1978) [examined]. Richards, 1978: 358

Female: length of fore wing $10.5 \mathrm{~mm}$; clypeus wider than high, H/WCLP about 0.90 , apex narrowly truncate, clypeus less extensively in contact with eye, free upper part of lateral margin longer, more than 0.33 times clypeus height at middle; humeral angle well developed but not produced into lobe, pronotal carina mostly reduced at center, not lamellate there, nearly straight, not reflexed at sides, with a very narrow lamellar portion, total width of carina about 1.08 times that of mesoscutum, sides of the pronotum as seen from above not noticeably converging forwards; mesoscutum as long as wide, L/WMS 1.0; fore wing well-elongated, LDIS/HMP about 2.43; inner claw of hind tarsus with the apex pointed, but not acute; propodeal valve rather narrow, with subquadrate outline; first segment of metasoma moderately elongate, LSI/ HMP 1.14, about 2.4 times wider at the apex than at the basal petiole, spiracles not noticeably prominent.

Color: yellow with black marks on head and mesosoma, metasoma entirely black (see Zikán 1949 and Richards 1978).

Male: unknown.

Nest: unknown.

Distribution: Peru: Chanchamayo.

Remarks: Richards (1978) commented on differences in length of the first metasomal segment amongst specimens of the type series of $M$. flavoniger, and on the taxonomic position of the species with respect to the group of M. cassununga (von Ihering, 1903). Zikán's M. flavoniger is definitely a member of the group of $M$. paraguayensis in regard of the just partial reduction of the pronotal carina, the flattened metanotum, and the narrowly pointed (but not sharp) inner claw of the hind tarsus. 
Examined material: Peru: (Chanchamayo) Oreja de Capelo $1.600 \mathrm{~m}$, 1.v.1943 (female, Paralectotype), Weyrauch (IOC).

\section{Mischocyttarus tayacaja sp. nov.}

(Fig. 5B)

Description. Female: length of fore wing $11 \mathrm{~mm}$; head nearly as high as wide in frontal view, FHH/INTOW 0.98; clypeus wider than high, H/WCLP 0.91 , apex narrowly truncate, clypeus less extensively in contact with eye, free upper part of lateral margin longer, more than 0.33 times clypeus height at middle; malar space narrow; tentorial pit a little closer to eye margin than to antennal socket; occeli as in an equilateral triangle, POL/OOL about $1 / 2$; occiput rounded, carina absent; gena considerably narrower than the upper lobe of the eye; pronotum with lateral fovea, central part of the anterior margin of pronotum with the lamella wide but not reflexed, region immediately behind produced into a secondary margin projecting over the lamella; humeral angle well developed but not produced into lobe, pronotal carina mostly reduced at center, not lamellate there, nearly straight, not really reflexed at sides, with a very narrow opaque lamellar portion, total width of carina about 1.08 times larger than that of mesoscutum, sides of the pronotum as seen from above not noticeably converging forwards; mesoscutum a little longer than wide, L/WMS 1.06; fore wing well elongated, LDIS/HMP 2.44; inner claw of hind tarsus with the apex definitely acute; propodeum with median furrow long, quite deep and moderately wide, developed on $4 / 5$ of the length of propodeal dorsum, propodeal valve narrow, with a round outline; first segment of metasoma wellelongated, LSI/HMP 1.16 , but also very wide distally, 2.72 times wider at the apex than at the basal petiole, spiracles not noticeably prominent, petiole cylindrical, not flattened ventrally.

Sculpture: relatively stronger on frons, pronotum, mesoscutum, mesopleuron and propodeum, but mostly consisting of small punctures; clypeus a little shining with small punctures and scattered inconspicuous larger ones, area close to the ventral margin finely reticulate and moderately shining, with a few isolated large punctures; mesopleuron with granulate aspect, little shining.

Vestiture: eyes bare; hairs beneath gena only moderately long.

Color: black; apical teeth of mandible, antennal flagellum beneath at the apex, basal dorsal aspect of scape, gena especially on dorsal half, narrow areas near pronotal anterior and posterior margins, diffuse marks on humerus and upper mesepisternal plate, a pair of such marks on scutellum, reddish brown; mandible, clypeus except for upper marginal area, inner orbit to ocular sinus, ventral parts of gena and lower half of outer orbit, pronotal spot adjacent to fovea, anterior aspect of fore coxa, anterior spot on mid coxa, extensive marks on fore and mid trochanters and femora, less extensive anterior mark on hind femur, all tibiae and tarsi, yellow; hind tibia a little darker, last segments of mid and hind tarsi blackish; wing hyaline, costal region amber, veins brown.

Male: unknown.
Nest: unknown.

Distribution: Peru: Huancavelica.

Etymology: the specific epithet "tayacaja" is a composite of two words in the Quechua language referring respectively to an Andean plant (tuya), and to an aspect of the regional landscape (ccacca; "peñasco", hill) (http://www. munitayacaja.gob.pe/tayacaja/09.php). Tayacaja is also the name of one of the provinces of the Peruvian department of Huancavelica. It is used here as a noun in apposition.

Remarks: The female holotype is the only known representative of this species. It is larger than usual in its group and has a sharply pointed hind tarsal claw. However, the structure of the clypeus and face, and of the pronotum indicate membership in the $M$. paraguayensis group.

Type Material: Holotype: Female, Peru, Huancavelica, Campo Arminõ, 1600m, 27.vii.1976 (female), R. Garcia (NHM)

\section{Mischocyttarus suzannae sp. nov.}

(Figs. 5E and 6A)

Description. Female: length of fore wing $9 \mathrm{~mm}$; head nearly as high as wide in frontal view, FHH/INTOW about 1.0; clypeus wider than high, H/WCLP about 0.92 , apex narrowly truncate, clypeus less extensively in contact with eye, free upper part of lateral margin longer, more than 0.33 times clypeus height at middle; malar space narrow; tentorial pit a little closer to eye margin than to antennal socket; occeli as in an equilateral triangle, $\mathrm{POL} / \mathrm{OOL}$ about $1 / 2$; occiput rounded, carina $\mathrm{ab}-$ sent; gena considerably narrower than the upper lobe of the eye; pronotum with lateral fovea, central part of the anterior margin of pronotum with the lamella wide but not reflexed, region immediately behind produced into a secondary margin projecting over the lamella; humeral angle poorly developed, approaching a round profile, not at all forming lobe, pronotal carina mostly reduced at center, not lamellate there, nearly straight, not really reflexed at sides, with a very narrow lamellar portion, total width of carina about 1.07 times larger than of mesoscutum, sides of the pronotum as seen from above a little more converging forwards; mesoscutum about as long as wide, L/WMS 1.0; fore wing very short, LDIS/HMP only about 2.13; inner claw of hind tarsus with the apex roundly pointed, not acute; propodeum with median furrow long, rather deep and narrow, developed on 5/6 of the length of propodeal dorsum, propodeal valve moderately wide, with triangular outline; first segment of metasoma variable in length, LSI/HMP from 1.02 to 1.11 , apical width varying from 2.18 to 2.31 times that at the basal petiole, spiracles not noticeably prominent, petiole cylindrical, not flattened ventrally.

Sculpture: indistinct, disk of clypeus considerably shining, mostly with very small punctures, larger ones rare and inconspicuous, area close to the ventral margin finely reticulate and considerably shining, with a few isolated large punctures; upper interantennal area and frons with minute punctures arranged into a dense and dull granulate pattern; mesopleuron with very fine indistinct punctures, considerably shining. 
Vestiture: eyes bare; most body parts covered with a short appressed shining whitish pubescence, hairs beneath gena very short.

Color: black; base of mandible, upper third of clypeus, dorsal area on gena, anterior face and lateral area of pronotum, spots on meso and metapleura, propodeum, legs and first metasomal tergum, reddish brown; apex of mandible, antennal flagellum beneath, tegula, light testaceous; ventral Ushaped mark on clypeus, inner orbit to ocular sinus, two minute spots below antennal sockets, two small streaks on interantennal area above, pronotal carina, pronotal posterior margin, area adjacent to fovea, proepisternum, anterior aspect of fore coxa, anterior transversal marks and axillary crests of scutellum and metanotum, two small elongate spots on propodeum and valvular region, very narrow distal band on proximal metasomal terga, yellow; wing hyaline with light yellow-brown veins; last segment of mid and hind tarsi darker brown.

Male: length of fore wing $9.0 \mathrm{~mm}$; clypeus narrowly separated from eyes, considerably wider than high, H/WCLP about 0.90 , ventral angle obtuse, apex narrowly round; antenna with the scape relatively shorter and wider, ventral surface of the flagellum with tyloids reduced or fragmented, apex of the antenna short and broad, antennomere 13 about 2.0 times longer than wide; clypeus covered with short appressed silvery hairs a little more conspicuous than in female; hairs on frons and gena beneath not very different of the condition in female.

Color: similar to female, but with more extensive yellow marks, i.e. nearly all the mandible and clypeus (the latter only with a central dark mark), most of supra clypeal plate and interantennal area, inner orbit broadly, outer orbit (with a short interruption), pronotal ventral angle, proepisternum and fore coxa, spot on upper mesepisternal plate, mesopleuron medio-ventrally, base of mid coxa anteriorly, narrow bands on proximal metasomal terga.

Nest: a very elongate comb (Fig. 6A), quite similar to some nests figured by Zikán (1949) for the Brazilian southeastern fauna (eg. Fig. 392 nest of "M. ornatulus", and Fig. 401 nest of " $M$. costalimai").

Distribution: Brazil: Pará.

Etymology: the specific epithet is homage to Ms. Suzanna S. Silva, student of the Neotropical social wasps and collector of part of the type specimens and the nest in Serra dos Martírios-Andorinhas.

Remarks: This species is definitely a member of the $M$. paraguayensis group based on the structure of the head of the female, and the forms of the male antenna and clypeus. The very short fore wing is truly remarkable as well as the geographical positions of the sites recorded for the known specimens, well within the limits of southeastern Amazonia, nearby the confluence of the Tocantins and Araguaia rivers.

Type Material: Holotype: Female, Brazil, Pará, São Geraldo do Araguaia, Serra dos Martírios-Andorinhas, 27.x.2011, S. S. Silva (MPEG). Paratypes:Brazil: Pará, São Geraldo do Araguaia, Serra dos MartíriosAndorinhas, 27.x.2011 (10 females, 6 males) S. S. Silva (MPEG); Pará, Tucuruí, Puraquequara, 27.viii.1980 (female), Nunes de Melo (INPA).

\section{CONCLUDING REMARKS}

The balance between synonymization and new taxa description in this work points to a new picture of diversity in the species groups here considered, to the contrary of the situation described by Richards (1978). Seven new species are proposed in the alfkenii and basimacula group (M. baconi Starr would be an eighth additional species), with five new synonymies (four of subspecific rank). On the other hand, only two new species are described in the paraguayensis and bahiae group, while fifteen new synonymies are proposed (all of specific rank). So while species number increased from three to twelve in the first group, a marked reduction resulted in the second group, from nineteen to only six species. In geographic terms, these numbers reflect higher diversity in northern Andean areas than in the Brazilian Atlantic region. Quite remarkably, Amazonian and Guyanan lowlands count only four species, if we consider the peripherally distributed new species $M$. suzannae and M. arawak.

In Fig. 7, four general distributions types can be perceived for the alfkenii-basimacula group: (1) M. basimacula and M. waunan occurring from México to trans-Andean areas in Ecuador, Colombia and Venezuela (Fig. 7A); (2) species that have subalar area unpainted occurring in transAndean areas and along the Caribbean coast (M. muisca, M. awa, M. embera, M. uniformis, M. trinitatis, M. baconi) (Fig. 7B); (3) species occurring in Amazonia-Guyana ( $M$. alfkenii, M. arawak) (Fig. 7A); and (4) species with periAmazonian distribution (M. flavicornis, M. achagua) (Fig. 7A). With respect to the paraguayensis-bahiae group, the species are mainly distributed through eastern South America, from the south bank of the Rio da Plata estuary to Ceará state in Brazil (Fig. 7C). Specimens of M. bahiae from Ceará were collected by Ducke in Serra de Baturité, in a region of moderately elevated highlands (600 meters or more) containing fragments of moist forests in the otherwise semi-arid Caatinga domain (Ab'Saber 1977; Andrade $\&$ Lins 1964). Several authors have pointed to historical relations of these forests ("brejos de altitude") with the Brazilian Atlantic Forest (see Borges-Nojosa \& Caramaschi 2003). However, three species of this group occur in more isolated and biogeographically unrelated localities (in terms of the present-day biome distributions): $M$. flavoniger and M. tayacaja in sub-Andean Peru, and M. suzannae within the southeastern limits of Amazonia. The distribution of M. suzannae as an Amazonian representative of the group of $M$. paraguayensis and bahiae may possibly be explained in the context of historical relationships between South American humid forests (see Amorim 2001; Cracraft \& Prum 1988). Amorim's hypothesis of "Dos Amazonias" maintains that southeastern Amazonian areas would have closer historical relationships with Atlantic Forest than with northwestern Amazonia. Unfortunately, it has been impractical to study the phylogenetic relationships within these Mischocyttarus species groups based only on morphological characters given the observed form homogeneity. 


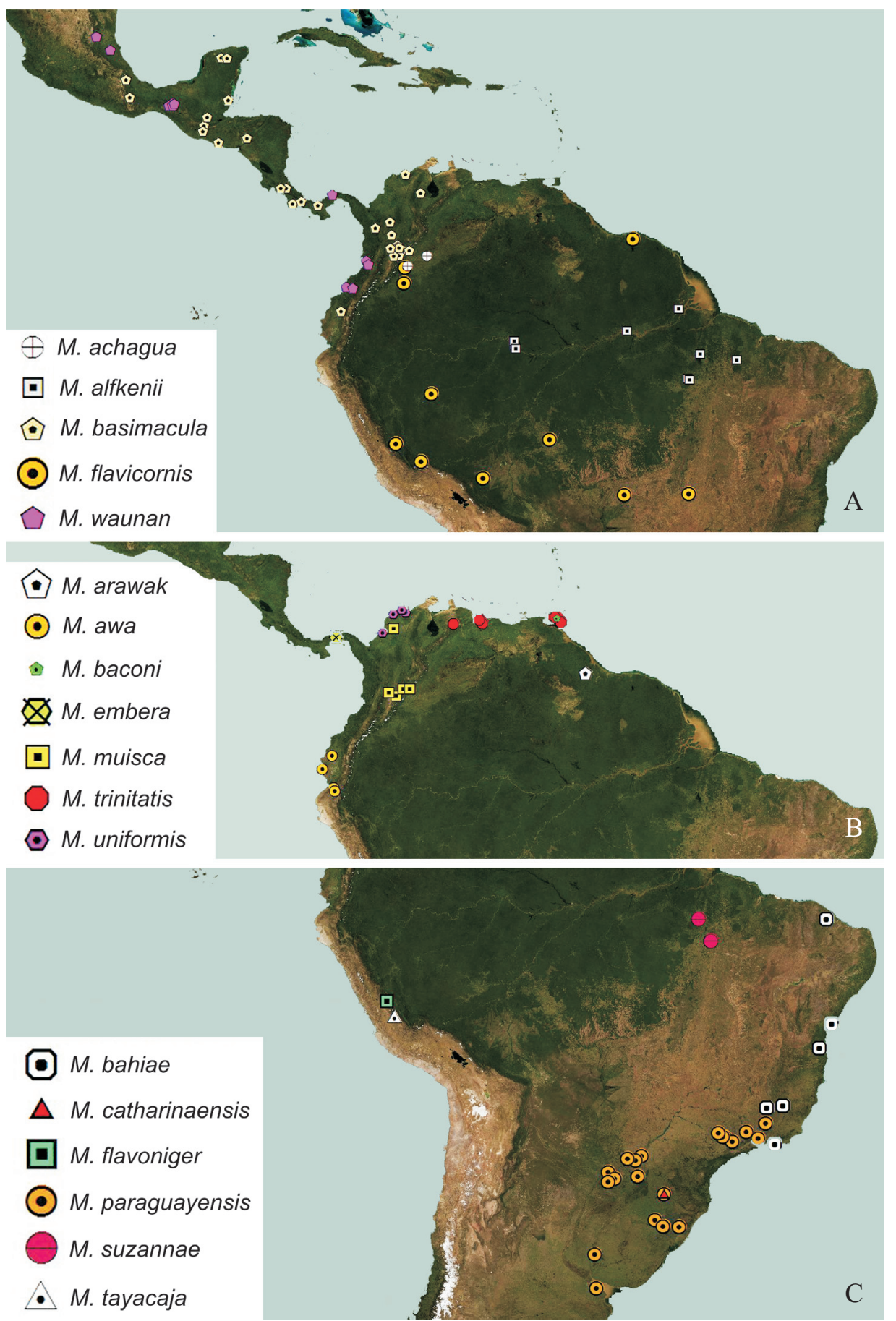

Fig. 7. Distributions of species of the groups of Mischocyttarus alfkenii and M. basimacula (A and B), and M. paraguayensis and M. bahiae (C).

\section{ACKNOWLEDGMENTS}

I would like to thank all of the curators of the collections which provided specimens for this study for their collaboration and patience. In particular, I thank Dr. Jane Costa, Dr. Márcio Félix, and Ms. Daniele Cerri for their hospitality at Instituto Oswaldo Cruz in Rio de Janeiro; Dr. Carlos Roberto Ferreira Brandão at the Museu de Zoologia in São Paulo; Dr. Gavin Broad at the Natural History Museum in London; and Dr. Carlos
Sarmiento at the Universidad Nacional de Colombia in Bogotá who also read a previous version of the manuscript. Dr.Claudia Lopez kindly helped with correct use of indigenous names. I am also greatful for the valuable suggestions made by two referees. A grant for visiting the London Museum was conceded by the Brazilian Ministry of Science, Technology and Inovation. The Brazilian Government Program for Study of Amazonian Biodiversity (PPBIO) also gave support for travelling to Rio de Janeiro (IOC) and São Paulo (MZSP). 


\section{REFERENCES}

Ab'Saber, A.N. 1977. Os domínios morfoclimáticos na América do Sul: primeira aproximação. Geomorfologia 53: 1-23.

Amorim, D.S. 2001. Dos amazonias, p. 245-255. In: Llorente-Bousquets, J. \& J.J. Morrone (eds.). Introducción a la biogeografia en Latinoamérica: teorías, conceptos, métodos y aplicaciones. México, UNAM, p?.

Andrade, G.O. \& Lins, R.C. 1964. Introdução ao estudo dos "Brejos" pernambucanos. Arquivos do Instituto de Ciências da Terra (Universidade do Recife) 2: 21-34.

Arévalo, E., Zhu, Y., Carpenter, J.M. \& Strassmann, J.E. 2004. The phylogeny of the social wasp subfamily Polistinae: evidence from microsatellite flanking sequences, mitochondrial COI sequence, and morphological characters. BMC Evolutionary Biology 4: 8 .

Bequaert, J. 1933. The Nearctic social wasps of the subfamily Polybiinae (Hymenoptera: Vespidae). Entomologica Americana (new series) 13: 87-150.

Bequaert, J. \& Salt, G. 1931. New West Indian Diploptera. Annals of the Entomological Society of America 24: 765-797.

Borges-Nojosa, D.M. \& Caramaschi, U. 2003. Composição e Análise Comparativa da Diversidade e das Afinidades Biogeográficas dos Lagartos e Anfisbenídeos (Squamata) dos Brejos Nordestinos, p. 489-540. In: Leal, I., Silva, J.M.C. \& Tabarelle, M. (Org.). Ecologia e Conservação da Caatinga. v. 01, Recife, UFPE.

Cameron, P. 1906. On some Vespidae from Belize. Invertebrata Pacifica 1: $41-69$.

Carpenter, J. M. 1999. Taxonomic notes on paper wasps (Hymenoptera: Vespidae; Polistinae). American Museum Novitates 3259: 1-44.

Cooper, M. 1996a. The subgenus Monogynoecus Richards of Mischocyttarus de Saussure (Hym., Vespidae, Polistinae) with descriptions of two new species. Entomologist's Monthly Magazine 132: 23-28.

Cooper, M. 1996b. The mendax group of Mischocyttarus (Hym., Vespidae, Polistinae) with descriptions of new species. Entomologist's Monthly Magazine 132: 273-280.

Cooper, M. 1997a. A new subgenus of Mischocyttarus de Saussure (Hym., Vespidae). Entomologist's Monthly Magazine 133: 117-129.

Cooper, M. 1997b. The subgenus Megacanthopus Ducke of Mischocyttarus de Saussure (Hym., Vespidae), with a key and three new species. Entomologist's Monthly Magazine 133: 217-223.

Cooper, M. 1998a. Two new species of Mischocyttarus (Hym., Vespidae) with notes on some members of the iheringi group. Entomologist's Monthly Magazine 132: 89-93.

Cooper, M. 1998b. New species of the artifex group of Mischocyttarus de Saussure (Hym., Vespidae) with a partial key. Entomologist's Monthly Magazine 134: 293-306.

Cracraft, J. \& Prum, R.O. 1988. Patterns and processes of diversification: Speciation and historical congruence in some Neotropical birds. Evolution 42: 603-620.

Ducke, A. 1904. Sobre as vespidas sociaes do Pará. Boletim do Museu Goeldi 4: 317-374.

Ducke, A. 1905a. Nouvelles contributions à la connaissance des vespides sociales de 1'Amérique du Sud. Revue Entomologique (Caen) 24: 524.

Ducke, A. 1905b. Sobre as vespidas sociaes do Pará. (1o Supplemento). Boletim do Museu Goeldi 4: 652-698.

Ducke, A. 1907. Novas contribuições para o conhecimento das vespas (Vespidae sociales) da região neotropical. Boletim do Museu Goeldi 5: $152-199$.
Ducke, A. 1913. Zur Synonymie einiger Hymenopteren. Deutsche Entomologische Zeitschrift 1913: 330-333.

Ducke, A. 1918. Catalogo das vespas do Brazil. Revista do Museu Paulista 10: $314-374$.

Gadagkar, R. 1991. Belonogaster, Mischocyttarus, Parapolybia, and independent founding Ropalidia, p. 149-187. In: Ross, K.G. \& Matthews, H.W. (eds.). The Social Biology of Wasps. Ithaca, Cormell Universery Press, 798p.

Garcete-Barrett, B.R., 1999. Guía ilustrada de las avispas sociales del Paraguay (Hymenoptera: Vespidae: Polistinae). London, The Natural History Museum, $44 \mathrm{p}$.

Jeanne, R.L. 1980. Evolution of social behavior in the Vespidae. Annual Review of Entomology 25: 371-396.

Obrecht, E. \& Huber, C. 1993. Ducke type specimens and other Brazilian insect types in the Emil A. Goeldi collection in the Natural Museum Bern (Switzeland). An annotated catalogue. Jahrbuch des Naturhistorischen Museums 11: 163-184.

O’Connor, T.K., Starr, C \& Cameron, S.A. 2011. The Neotropical social wasp Mischocyttarus 'alfkenii' Ducke (Hymenoptera: Vespidae) is a pair of ethospecies. Systematic Entomology 36: 446-452.

Rau, P. 1933. Jungle bees and wasps of Barro Colorado Island. Kirkwood, $324 \mathrm{p}$.

Raw, A. 1996. Mischocyttarus (Monocyttarus) mamirauae, a new species of social wasp (Hymenoptera, Vespidae) from flooded Amazon forest. Boletim do Museu Paraense Emílio Goeldi (nova série) Zoologia 12: $3-8$.

Richards, O.W. 1941. The classification of the genus Mischocyttarus Saussure (Hymenopt., Vespidae). Proceedings of the Royal Entomological Society London (B) 10: 124-130.

Richards, O.W. 1945. A revision of the genus Mischocyttarus de Saussure (Hymen., Vespidae). Transactions of the Royal Entomological Society London 95: 295-462.

Richards, O.W. 1971. The biology of social wasps (Hymenoptera, Vespidae). Biological Review 46: 483-528.

Richards, O.W. 1978. The social wasps of the Americas, excluding the Vespinae. London, British Museum (Natural History), $580 \mathrm{p}$.

Saussure, H.F. de. 1853-1858. Études sur la familie des Vespides. 2. Monographie des guêpes sociales, ou de la tribu des Vespiens. Paris, Masson, and Geneva, J. Cherbuliez.

Silveira, O.T. 2006. Revision of the subgenus Kappa de Saussure of Mischocyttarus de Saussure (Hym.; Vespidae, Polistinae, Mischocyttarini). Zootaxa 1321: 1-108.

Silveira, O.T. 2008. Phylogeny of wasps of the genus Mischocyttarus de Saussure (Hymenoptera, Vespidae, Polistinae). Revista Brasileira de Entomologia 52: 510-549.

Wenzel, J.W. 1991. Evolution of nest architecture, p. 480-519. In: Ross, K.G. \& Matthews, H.W. (eds.). The Social Biology of Wasps. Ithaca, Cormell Universery Press, 798 p.

Wenzel, J.W. 1998. A generic key to the nests of hornets, yellowjackets, and paper wasps worldwide (Vespidae, Vespinae, Polistinae). American Museum Novitates 3224: 1-39.

Willink, A. 1953. Las especies argentinas de Mischocyttarus de Saussure (Hym., Vespidae). Acta Zoologica Lilloana 14: 317-340.

Zikán, J.F. 1935. Die sozialen Wespen der Gattung Mischocyttarus Saussure, nebst Beschreibung 27 neuen Arten (Hym., Vespidae). Arquivos do Instituto de Biologia Vegetal Rio de Janeiro 1: 143-203.

Zikán, J.F. 1949. O gênero Mischocyttarus Saussure (Hymenoptera, Vespidae), com a descrição de 82 espécies novas. Boletim do Parque Nacional do Itatiaia 1: 1-125. 